Review

\title{
In Vitro and In Vivo Effects of Flavonoids on Peripheral Neuropathic Pain
}

\author{
Paramita Basu ${ }^{1}$ and Arpita Basu ${ }^{2, *}$ \\ 1 Department of Anesthesiology, Pittsburgh Center for Pain Research, University of Pittsburgh School of \\ Medicine, Pittsburgh, PA 15213, USA; PAB171@pitt.edu \\ 2 Department of Kinesiology and Nutrition Sciences, School of Integrated Health Sciences, University of \\ Nevada, Las Vegas, NV 89154, USA \\ * Correspondence: Arpita.basu@unlv.edu; Tel.: +702-895-4576; Fax: +702-895-1500
}

Academic Editor: H.P. Vasantha Rupasinghe

Received: 26 February 2020; Accepted: 2 March 2020; Published: 5 March 2020

check for updates

\begin{abstract}
Neuropathic pain is a common symptom and is associated with an impaired quality of life. It is caused by the lesion or disease of the somatosensory system. Neuropathic pain syndromes can be subdivided into two categories: central and peripheral neuropathic pain. The present review highlights the peripheral neuropathic models, including spared nerve injury, spinal nerve ligation, partial sciatic nerve injury, diabetes-induced neuropathy, chemotherapy-induced neuropathy, chronic constriction injury, and related conditions. The drugs which are currently used to attenuate peripheral neuropathy, such as antidepressants, anticonvulsants, baclofen, and clonidine, are associated with adverse side effects. These negative side effects necessitate the investigation of alternative therapeutics for treating neuropathic pain conditions. Flavonoids have been reported to alleviate neuropathic pain in murine models. The present review elucidates that several flavonoids attenuate different peripheral neuropathic pain conditions at behavioral, electrophysiological, biochemical and molecular biological levels in different murine models. Therefore, the flavonoids hold future promise and can be effectively used in treating or mitigating peripheral neuropathic conditions. Thus, future studies should focus on the structure-activity relationships among different categories of flavonoids and develop therapeutic products that enhance their antineuropathic effects.
\end{abstract}

Keywords: chemotherapy-induced peripheral neuropathy; chronic constriction injury; diabetic neuropathy; diabetic painful neuropathy; flavonoids; oxidative stress; partial sciatic nerve injury; peripheral neuropathy; spared nerve injury; spinal nerve ligation

\section{Introduction}

Pain is defined as "an unpleasant sensory and emotional experience associated with actual or potential tissue damage, as described in terms of such damage" by the International Association for the Study of Pain [1]. Pain has been classified as acute vs. chronic based on duration only, not location or cause; bone or joint, cutaneous, deep or superficial, muscle or viscera based on location; and inflammatory, neuropathic or cancer based on cause or type [2]. Pain is relayed to the spinal cord by nociceptors, which are specialized primary afferent neurons capable of detecting noxious chemical, mechanical, and thermal stimuli [3]. According to the National Center for Complementary and Integrative Health, 11 million US adults suffer with "high impact chronic pain" [4]. Neuropathic pain is one of the most intense types of chronic pain conditions, resulting from the lesion in a somatosensory nervous system, which comprises of peripheral fibers ( $\mathrm{A} \beta, \mathrm{A} \delta$ and $\mathrm{C}$ fibres) and central neurons [5]. It affects $6.9-10 \%$ of the general population as reported in a systematic review conducted by van Hecke et al. [6]. The prevalence of neuropathic pain has increased $60 \%$ in severe clinical neuropathic conditions [7]. Most of the published data on neuropathic pain conditions mainly are based on studies 
in participants with low back pain [8-10], diabetes [11], nerve entrapment syndrome [8], as well as patients who attended neurology pain centers [12]. In the UK, the data indicated the prevalence of neuropathic pain to be $8 \%$ [13]. In United States, the prevalence rates of neuropathic pain were determined as $9.8 \%$ and $12.4 \%$ based on either clinical examination or self-reporting, respectively. However, the true estimate of neuropathic pain is difficult to obtain due to differences in defining neuropathic pain as well as differences in epidemiological methods used for assessment [14].

Central and peripheral are the two main types of neuropathic pain. Central encompasses central lesion, spinal cord injury, and diseases like stroke, multiple sclerosis [5], whereas peripheral includes peripheral nerve damage or injury [15]. Numerous studies have reported the effectiveness of tricyclic antidepressants, dextromethorphan, gabapentin, lamotrigine, phenytoin, pregabalin, opioids, and tramadol for treating painful sensory neuropathy $[16,17]$. These therapies reduce pain by $30-50 \%$ but are accompanied by side effects, such as sedation. For gabapentinoids, the number needed to treat neuropathic pain, in most of the meta-analyses fall between 7 and 10 [18]. Furthermore, the American Academy of Neurology recommends not to use opioids and sodium valproate in neuropathic pain [19].

Despite advances in pain research by employing combinatorial chemistries and high throughput screening techniques over past 50 years, natural products like plant secondary metabolites remain important molecules of interest in the treatment of different pain conditions [20]. The need for alternative agents, such as natural products with effective and safe analgesic properties, satisfactory tolerability, and proven efficacy in treating pain conditions, has been growing throughout the world [21-24]. The present review will focus on the flavonoids, mainly anthocyanins, chalcones, flavanones, flavones, flavonols, flavan-3-ol, and isoflavones and their effects on different peripheral neuropathic pain conditions.

\section{Flavonoids Classification, Structure, and Dietary Sources}

Table 1 lists the chemical structures of different sub-groups of flavonoids. The basic structure of flavonoid includes 15 carbon atoms in their backbone, arranged in the form of C6-C3-C6 backbone with two aromatic rings (A and B) linked to each other by three carbon atoms, which may or may not give rise to the third carbon atom, which may or may not form the third ring. Flavonoids are further classified into different sub-groups, such as anthocyanins, chalcones, flavanones, flavones, flavonols, flavan-3-ol, and isoflavones based on the hydroxylation pattern and chromane ring/ring C.

Table 2 summarizes the different sub-groups of flavonoids along with their examples and dietary sources. Anthocyanins are responsible for contributing colors in flowers, fruits, vegetables, and certain grains like black rice. The color of the anthocyanin is dependent on $\mathrm{pH}$ in which the red is formed under acidic condition, whereas blue is formed under basic condition as well as acylation and methylation of hydroxyl groups on A and B rings [25]. The most commonly reported anthocyanins, such as cyanidin, delphinidin and pelargonidin, and their methylated derivatives constitute $90 \%$ of total anthocyanin. The hydroxylation and methylation patterns on the B ring and glycosylation with different sugar units constitute more than 500 known anthocyanidins [26,27]. Chalcones are referred to as open-chain flavonoids due to the absence of the basic $\mathrm{C}$ ring from the flavonoid backbone. The major chalcones are arbutin, chalconaringenin, phloretin, and phloridzin. Chalcones are present in various fruits, such as apples, berries, strawberries, pears, tomatoes, certain wheat products, and hops or beers $[28,29]$. In case of isoflavones, the $B$ ring attached to the $C 3$ position of $C$ ring. Biochanin $A$, daidzein, formononetin, genistein, and glycitein, and puerarin are major isoflavones. Isoflavones are predominantly found in Leguminous plants, mainly in soybeans.

Another sub-group of flavonoids are flavanonols or dihydroflavonols, which include flavanones and their 3-hydroxy derivatives. The $\mathrm{C}$ ring in flavanones is saturated, which marks the difference between flavanone and flavone. The commonly reported flavanones are eriodictyol, hesperetin, and naringenin. Flavanones are generally present in citrus fruits. Taxifolin is an example of a well-known flavanonol found in citrus fruit [30,31]. Flavones, including their 3-hydrozy derivatives (flavonols), glycosides, methoxides, and other acylated products constitute the largest sub-group among all polyphenols. Flavones contain double bonds between positions 2 and 3 and a ketone in position 4 of 
the $\mathrm{C}$ ring. Flavones of the fruits and vegetables contain hydroxyl group in the 5 position of the A ring, sometimes hydroxyl group is present in 7 position of the A ring or $3^{\prime}$ and $4^{\prime}$ of the $\mathrm{B}$ ring, or other positions. Flavones are found as glycosides in flowers, fruits, leaves, and are also present in celery, chamomile, parsley, and red peppers. Apigenin, baicalein, isoorientin, luteolin, and tangeretin belong to flavone. Polymethoxylated flavones, such as tageretin, nobiletin and sinensetin are found in peels of the citrus fruit [32]. Flavonols contain hydroxyl group in 3 position of the $C$ ring, which might also be glycosylated. Flavonols also possess different hydroxylation, glycosylation and methylation patterns.

Flavonols are found in teas, red wine, along with a variety of fruits and vegetables, such as apples, berries, grapes, kale, lettuce, onions, and tomatoes. The most commonly studied flavonols are fisetin, kaempferol, morin, myricetin, and quercetin. Icariin is a prenylated flavonol glycoside, which is isolated from a traditional Chinese medicinal herb Epimedium and is used to treat bone fractures and osteoporosis [33]. On the other hand, flavanols are also known as flavan-3-ol because a hydroxyl group is always bound at the 3 position of ring C. Unlike flavonoids, there is no double bond between $\mathrm{C} 2$ and $\mathrm{C} 3$, and no $\mathrm{C} 4$ carbonyl in ring $\mathrm{C}$ of flavonols. The presence of hydroxylation at $\mathrm{C} 3$ enables flavonols to have two chiral centers on the $\mathrm{C} 2$ and $\mathrm{C} 3$ molecules, hence four possible diastereoisomers. Catechin is the isomer with trans configuration along with two stereoisomers (+)-catechin, $(-)$-catechin. Epicatechin is the cis configuration with two stereoisomers (+)-epicatechin and (-)-epicatechin. Flavanols are found in skins of fruits like apple, bananas, blueberries, grapes, peaches and pears. Catechins, such as epicatechin, epigallocatechin, epicatechin gallate, and epigallocatechin gallate (EGCG) are found in commercially available dietary supplements, beverages, as well as whole and processed foods [34,35].

Oligomeric proanthocyanidins can be A-type or B-type structure based on the interflavanic linkages. The monomers are linked through $\mathrm{C} 2-\mathrm{O}-\mathrm{C} 7$ or $\mathrm{C} 2-\mathrm{O}-\mathrm{C} 5$ bonding in A-type structure, whereas the bonding involves $\mathrm{C} 4-\mathrm{C} 6$ or $\mathrm{C} 4-\mathrm{C} 8$ in B-type structure. The common procyanidin dimers and trimers include procyanidin $\mathrm{B} 1$, procyanidin $\mathrm{B} 2$, procyanidin $\mathrm{A} 2$, and procyanidin $\mathrm{C} 1$, which is a trimer. Unique dimers like theaflavin are formed when tea flavanols are fermented $[36,37]$.

Table 1. Chemical structures of different sub-groups of flavonoids.

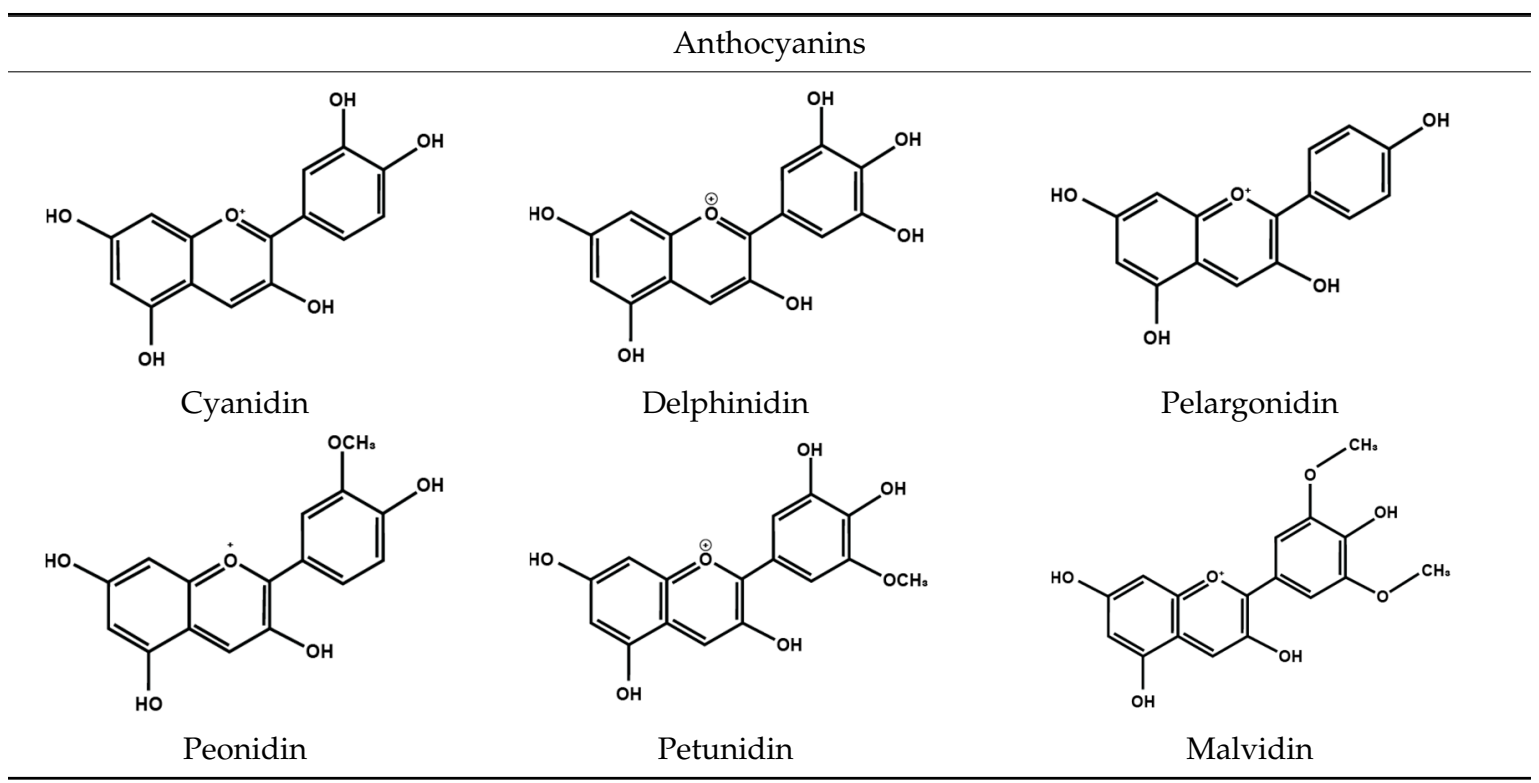


Table 1. Cont.

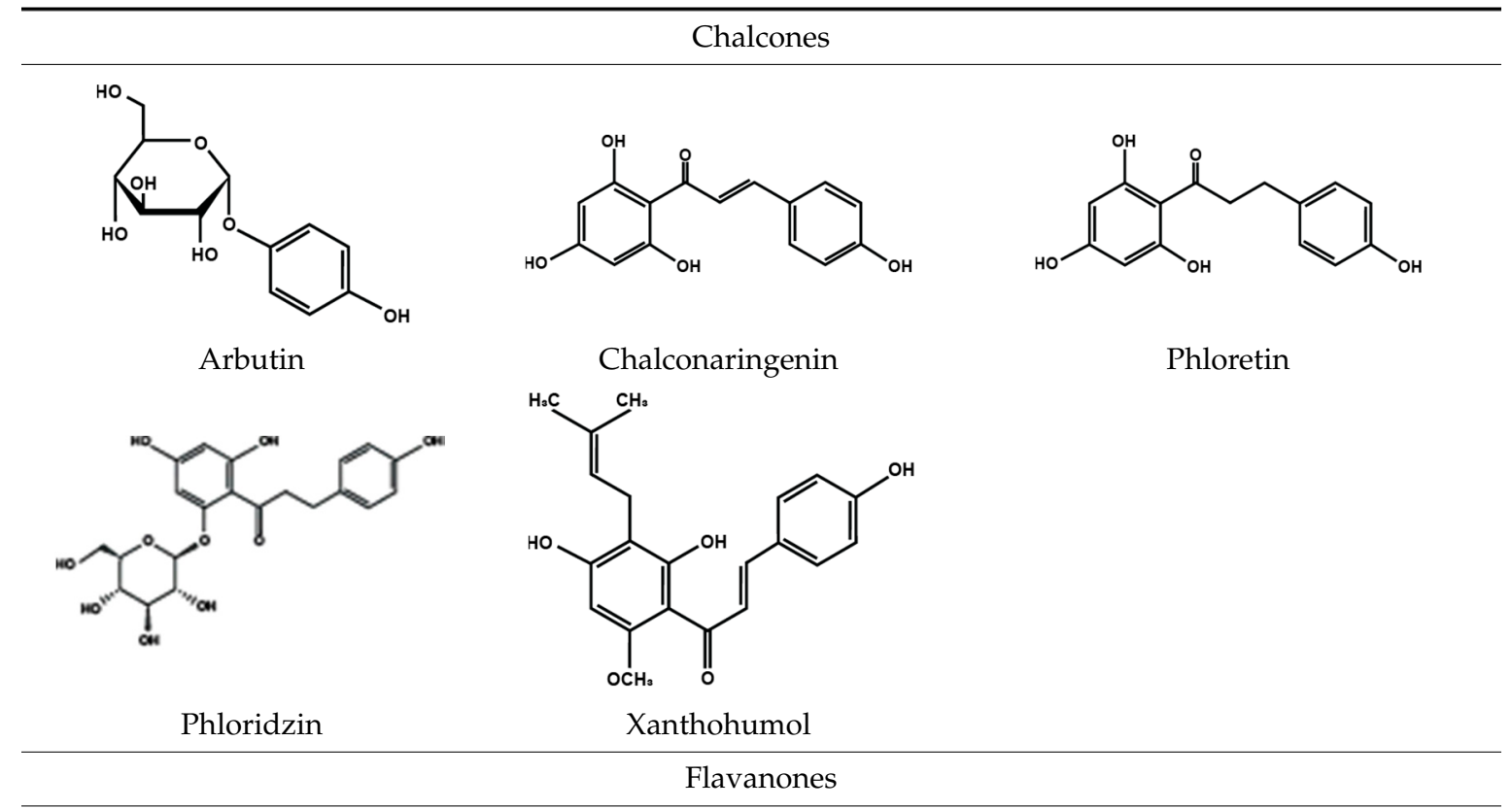<smiles>CCOC(Cl)(OC)OCC</smiles><smiles>COc1ccc([C@H]2CC(=O)c3c(O)cc(O)cc3O2)cc1O</smiles>

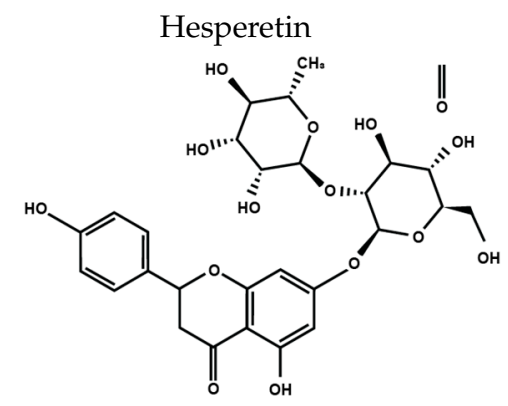
Naringin<smiles>COc1ccc(-c2cc(=O)c3c(O)cc(C[C@H]4OC(COC5OC(C)[C@H](C)[C@H](C)[C@H]5C)C[C@H](C)[C@H](O)[C@H]4O)cc3o2)cc1O</smiles>

Hesperidin<smiles>O=C1C[C@H](c2ccc(O)cc2)Oc2cc(O)cc(O)c21</smiles>

Naringenin Flavones<smiles>O=c1cc(-c2ccc(O)cc2)oc2cc(O)cc(O)c12</smiles>

Apigenin

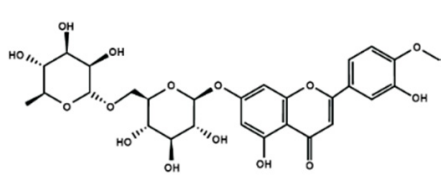

Diosmin<smiles>O=c1cc(-c2ccccc2)oc2cc(O)c(O)c(O)c12</smiles>

Baicalein

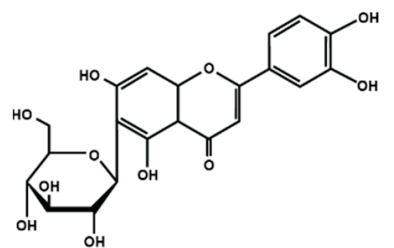

Isoorientin<smiles>O=c1cc(-c2ccccc2)oc2cc(OC3OC(C(O)O)C(O)C(O)C3O)c(O)c(O)c12</smiles>

Baicalin<smiles>O=c1cc(-c2ccc(O)c(O)c2)oc2cc(O)cc(O)c12</smiles>

Luteolin 
Table 1. Cont.
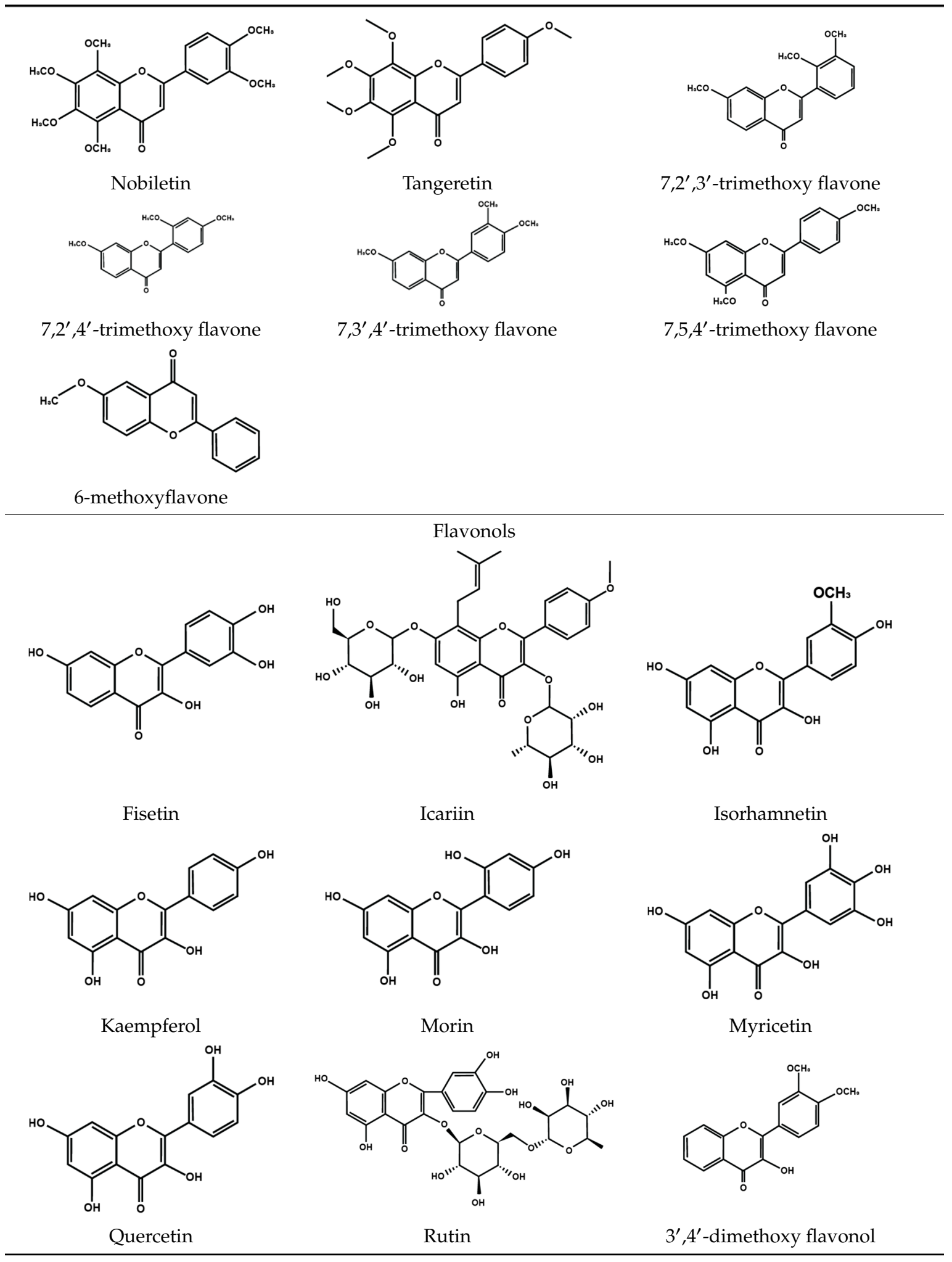
Table 1. Cont.

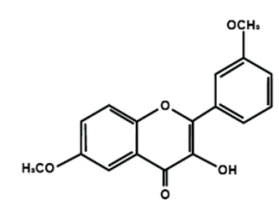

6,3'-dimethoxy flavonol<smiles>O=c1c(O)c(-c2ccccc2)oc2ccccc12</smiles>

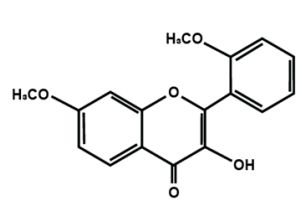

7,2'-dimethoxy flavonol<smiles>CC1=CCC(O)=CC1C1Oc2cc(O)ccc2C(O)C1O</smiles>

7,3'-dimethoxy flavonol

Flavonol

Flavan-3-ol<smiles>Oc1cc(O)c2c(c1)O[C@H](c1ccc(O)c(O)c1)[C@H](O)C2</smiles>

Catechin<smiles></smiles>

Proanthocyanidins
Isoflavones<smiles>COc1ccc(-c2coc3cc(O)cc(O)c3c2=O)cc1</smiles>

Biochanin A<smiles>O=c1c(-c2ccc(O)cc2)coc2cc(O)cc(O)c12</smiles><smiles>O=c1c(-c2ccc(O)cc2)coc2cc(O)ccc12</smiles>

Daidzein<smiles>COc1cc2c(=O)c(-c3ccc(O)cc3)coc2cc1O</smiles><smiles>O=C(O[C@H]1Cc2c(O)cc(O)cc2O[C@H]1c1cc(O)c(O)c(O)c1)c1cc(O)c(O)c(O)c1</smiles>

Epigallocatechin gallate

(-)-epicatechin<smiles>COc1ccc(-c2coc3cc(O)ccc3c2=O)cc1</smiles>

Formononetin

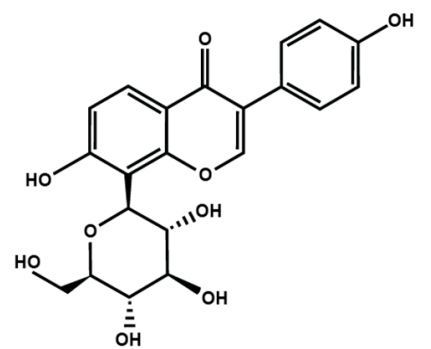

Puerarin 
Table 2. Different sub-groups, examples, and dietary sources of flavonoids.

\begin{tabular}{|c|c|c|c|}
\hline $\begin{array}{l}\text { Flavonoid } \\
\text { Subgroup }\end{array}$ & Example & Dietary Sources & References \\
\hline Anthocyanins & $\begin{array}{l}\text { Cyanidin } \\
\text { Delphinidin } \\
\text { Pelargonidin } \\
\text { Peonidin } \\
\text { Petunidin } \\
\text { Malvidin }\end{array}$ & $\begin{array}{l}\text { Edible red (red clover, red hibiscus, red pineapple sage, } \\
\text { pink blossom); blue (blue chicory, blue rosemary, } \\
\text { cornflower); purple (purple mint, purple passionflower, } \\
\text { purple sage); berries, blackcurrants, black carrot, purple } \\
\text { potato, red cabbage }\end{array}$ & Khoo et al. [25] \\
\hline Chalcones & $\begin{array}{l}\text { Arbutin } \\
\text { Chalconaringenin } \\
\text { Phloretin } \\
\text { Phloridzin } \\
\text { Xanthohumol }\end{array}$ & Hops, hop containing beers and herbal teas & $\begin{array}{l}\text { Stevens et al. [38]; } \\
\text { Zhao et al. [29] }\end{array}$ \\
\hline Flavanones & $\begin{array}{l}\text { Eriodictyol } \\
\text { Hesperetin } \\
\text { Hesperidin } \\
\text { Naringenin }\end{array}$ & $\begin{array}{l}\text { Citrus fruits like lemon, lime mandarin, orange; grapefruit, } \\
\text { herbal tea (Honeybush tea), potato }\end{array}$ & $\begin{array}{l}\text { Tomás-Barberán \& } \\
\text { Clifford [39] }\end{array}$ \\
\hline Flavones & $\begin{array}{l}\text { Apigenin } \\
\text { Baicalein } \\
\text { Diosmin } \\
\text { Isoorientin } \\
\text { Luteolin } \\
\text { Nobiletin } \\
\text { Tangeretin }\end{array}$ & $\begin{array}{l}\text { Dry herbs and teas (Roman Chamomile flowers, tansy leaf, } \\
\text { fenugreek seed, rosemary, sage, black tea, green tea, } \\
\text { oolong tea); juices and wines (bergamot juice, mandarin } \\
\text { orange juice, citron juice, orange juice); fruits, vegetables, } \\
\text { olive oil and honey (kiwi, spinach, parsley, celery, lettuce, } \\
\text { artichoke, broccoli, watermelon, pumpkin, peas); cereals } \\
\text { and legumes (chickpea, fava pea, field pea, wheat grain, } \\
\text { black, brown, red and white rice) }\end{array}$ & $\begin{array}{c}\text { Engelhardt et al., } 1993 \text { [40]; } \\
\text { Carnat et al., } 2004 \text { [41]; } \\
\text { Caristi et al., } 2006 \text { [42]; } \\
\text { Wojdylo et al., } 2007 \text { [43]; } \\
\text { Wijaya \& Mares, } 2012 \text { [44]; } \\
\text { Pereira-Caro et al., } 2013 \text { [45]; } \\
\text { Magalhães et al. [46] }\end{array}$ \\
\hline Flavonols & $\begin{array}{c}\text { Fisetin } \\
\text { Isorhamnetin } \\
\text { Kaempferol } \\
\text { Morin } \\
\text { Myricetin } \\
\text { Quercetin } \\
\end{array}$ & $\begin{array}{l}\text { Fruits (apples, berries, grapes), vegetables (curly kale, leek, } \\
\text { lettuce, onions, tomatoes), tea, red wine }\end{array}$ & Egert \& Rimbach [47] \\
\hline Flavan-3-ol & $\begin{array}{c}\text { Catechin } \\
\text { (-)-Epicatechin } \\
\text { Epigallocatechin } \\
\text { gallate }\end{array}$ & $\begin{array}{l}\text { Dietary supplements, beverages, whole and processed } \\
\text { foods }\end{array}$ & Prior et al. [34]; Si et al. [35] \\
\hline Isoflavones & $\begin{array}{l}\text { Biochanin A } \\
\text { Daidzein } \\
\text { Formononetin } \\
\text { Genistein } \\
\text { Glycitein } \\
\text { Puerarin }\end{array}$ & $\begin{array}{l}\text { Kidney beans, lentils, mung bean sprouts, mung beans, } \\
\text { red clover, soy products, soybeans, soy products }\end{array}$ & $\begin{array}{l}\text { Ho et al. [48]; Zaheer and } \\
\text { Akhtar [49] }\end{array}$ \\
\hline
\end{tabular}

\section{Biosynthesis of Flavonoids}

Flavonoids are synthesized through the phenylpropanoid pathway by the transformation of phenylalanine into 4-coumaroyl-CoA, which enter the flavonoid biosynthesis pathway. All flavonoids are derived from the chalcone scaffold, which is biosynthesized by the enzyme chalcone synthase (CHS). The enzyme CHS catalyzes the condensation and subsequent intramolecular cyclization of three acetate units onto the p-coumaroyl-CoA, which is the end product of the general phenylpropanoid pathway. Following the enzymatic reaction catalyzed by $\mathrm{CHS}$, oxoglutarate-dependent $\mathrm{Fe}^{2+/ 3+}$ dioxygenases, hydroxylases, isomerases, and reductases modify the basic flavonoid backbone and lead to the synthesis of a variety of flavonoid subclasses, such as anthocyanins, chalcones, flavanones, flavones, flavonols, and isoflavones. Chalcone isomerase stereospecifically directs the additional cyclization of chalcones to form flavones.

The acyltransferases, glycosyltransferases, and methyltransferases add acyl, sugar, and/or methyl moieties, respectively, and thus alter the solubility, reactivity, and interactions of flavonoids with different cellular targets [50,51].

\section{Neuropathic Pain}

Neuropathic pain is defined as "pain caused by a lesion or disease of the somatosensory nervous system" by the International Association for the Study of Pain [52]. Somatosensory nerves arise from 
fascia, joints, muscles, skin, and include various receptors, like thermoreceptors, mechanoreceptors, chemoreceptors, pruriceptors, and nociceptors that send signals to the spinal cord and eventually to the brain for further processing [5]. Neuropathic pain is difficult to treat effectively and is associated with significant impairment of health conditions and economic burden [53,54]. One of the largest studies on neuropathic pain conducted in US showed the prevalence rate of neuropathic pain being 9.8\% among adults in Minnesota [55].

Neuropathic syndrome can be divided into two categories: peripheral and central neuropathic pain conditions. Central neuropathic pain is due to a lesion or disease of the spinal cord and/or brain. Cerebrovascular disease like central post-stroke pain (CPSP) affects the central somatosensory pathway as well as the neurodegenerative diseases mainly Parkinson disease cause central neuropathic pain [56]. Furthermore, spinal cord lesion or diseases like multiple sclerosis, transverse myelitis and neuromyelitis optica, spinal cord injury, and syringomyelia lead to neuropathic pain [57].

The consequences of peripheral lesion or disease lead to the development of peripheral neuropathic conditions, respectively. The pathology of peripheral disorders, which cause neuropathic pain, mainly involve unmyelinated $C$ fibers and myelinated $A \beta$ and $A \delta$ fibers [58]. Some of the common and typically irreversible peripheral neuropathic conditions include alcoholic neuropathy, cancer pain, Charcot-Marie-Tooth disease, chemotherapy-induced peripheral neuropathy (CIPN), chronic inflammatory demyelinating polyneuropathy, complex regional pain syndrome, diabetic painful neuropathy (DPN), human immunodeficiency virus painful sensory neuropathy, phantom limb pain, post-herpetic neuralgia, erythromelalgia, and many more.

\section{Chemotherapy-Induced Peripheral Neuropathy (CIPN)}

The use of different chemotherapy agents and other cancer treatments will lead to the damage of the nerves away from the brain and spinal cord. CIPN is one of the most common neuropathies caused by antineoplastic agents [59]. The prevalence of CIPN is age-related, varying from $19 \%$ to more than $85 \%$ [60]. The highest incidence of CIPN has been reported in the case of platinum-based $(70-100 \%)$, taxanes (11-87\%), thalidomide and its analogues (20-60\%), and ixabepilone (60-65\%) [61]. The common symptoms for CIPN include sensitivity to cold and heat, tingling or pins-and-needles sensation, pain, burning, or numbness, difficulty with fine motor skills, and muscle weakness [62]. In general, CIPN symptoms arise after weeks or months after completion of the chemotherapy, mainly dependent on the cumulative dose of the drug [63]. Paclitaxel and oxaliplatin induce severe neuropathy during or immediately after infusion [64].

\section{Effects of Flavonoids on CIPN}

Table 3 summarized the effects of flavonoids on CIPN. Platinum compounds play an important antitumor drug that is widely used in the treatment of various solid tumors. Cisplatin was the first synthesized drug in 1864 after carboplatin. Oxaliplatin is a third-generation platinum drug with significant cytotoxicity and diminished antitumoral resistance [65,66]. Azevedo et al. [67] reported that quercetin and rutin inhibited oxaliplatin-induced cold and mechanical nociceptive thresholds. The histopathological analysis of the skin harvested from the paws of the mice subjected to oxaliplatin-induced peripheral neuropathy showed that quercetin and rutin prevented the formation of little lacunar spaces between collagen fibers. Quercetin or rutin also prevented oxaliplatin-induced lipid peroxidation reflected by malondialdehyde (MDA) levels in the spinal cord samples. Finally, immunohistochemical analysis of the dorsal horn of the spinal cord showed that both quercetin and rutin reduced Fos expression, whereas only quercetin inhibited nitrotyrosine, and inducible nitric oxide synthase (iNOS) immunoexpression. Schwingel et al. [68] reported that quercetin nanoemulsion, and rutin reduced oxaliplatin-induced mechanical allodynia. Furthermore, the study showed that quercetin, quercetin nanoemulsion, and rutin decreased the nociceptive biomarker c-Fos in the spinal cord, indicating that phytochemicals modulated the oxaliplatin-induced neuropathy at the central level [58]. The antinociceptive activity of 6-methoxyflavone was investigated in a rat model 
of CIPN [69]. Thereby, 6-methoxyflavone significantly attenuated cisplatin-induced mechanical allodynia by increasing paw withdrawal threshold and thermal hypoalgesia by alleviating paw thermal threshold. Further, 6-methoxyflavone induced antinociceptive activity was without associated side effects, such as motor impairment exemplified by rotarod endurance latency [69]. In another study, naringin prevented cisplatin-induced behavioral impairment and anxiolytic-like behavior in the elevated T-maze test. Treatment of naringin significantly and dose-dependently prevented various biochemical and molecular alterations in the aged rats treated with cisplatin. Naringin prevented the increase in acetylcholinesterase activity and decrease $\mathrm{Na}^{+}, \mathrm{K}^{+}$-ATPase, $\mathrm{Ca}^{2+}$-ATPase, and $\mathrm{Mg}^{2+}$-ATPase activities induced by cisplatin in hippocampus. Administration of naringin with cisplatin significantly reduced oxidative biomarkers, such as lipid peroxidation, protein carbonylation, and hydrogen peroxide formation, in the hippocampus of aged rats. Naringin together with cisplatin prevented the increase in reactive oxygen species (ROS), nitric oxide (NO) level, messenger ribonucleic acid (mRNA) expression of iNOS, alteration of nonenzymatic (ascorbic acid, GSH) and antioxidant enzymes, such as superoxide dismutase (SOD), catalase (CAT), and glutathione peroxidase (GPx) activities in the hippocampus in aged rats [70]. The above study summarized the effects of naringenin in cisplatin-induced oxidative-stress-mediated inflammation in cognitive dysfunction and cognitive deficits in chemotherapy-induced peripheral neuropathy [70].

Flavonoids have also been reported in ameliorating neuropathic manifestation induced by paclitaxel [71-73]. Gao et al. [71] reported that quercetin significantly increased thermal hyperalgesia and mechanical allodynia in both paclitaxel treated rats and mice. In vitro treatment of quercetin on RBL-2H3 cells dose-dependently and significantly decreased the release of histamine, whereas in vivo quercetin treatment significantly reduced histamine release in the plasma of rats. Quercetin also dose-dependently decreased the protein expressions of protein kinase $C \varepsilon(P K C \varepsilon)$ and transient receptor potential V1 ion channels (TRPV1) in spinal cord and dorsal root ganglion (DRG) neurons of rats and spinal cords of mice. Furthermore, forty days of both low and high dose of quercetin treatments inhibited the translocation of PKC $\varepsilon$ from the cytoplasm to the membrane in the spinal cord and DRG of paclitaxel treated rats. Gui et al. [74] found that icariin treatment significantly alleviated paclitaxel-induced mechanical allodynia in the long term by suppressing the expressions of pro-inflammatory markers, such as tumor necrosis factor $\alpha$ (TNF- $\alpha$ ), interleukin $1 \beta$ (IL-1 $\beta)$, and interleukin 6 (IL-6), astrocytes activation, nuclear factor kappa-light-chain-enhancer of activated B cells (NF- $\mathrm{B}$ ) phosphorylation (p65) in the spinal cord. Icariin also reversed paclitaxel-induced downregulation of spinal sirtuin 1 (SIRT1) expression and H4 acetylation. Activation of SIRT1 and H4-K16 acetylation in the spinal cord has been reported to alleviate neuropathic pain [75]. Therefore, the study concluded that icariin suppressed paclitaxel-induced neuroinflammation and mechanical allodynia in a SIRT-1-dependent manner. Nadipelly et al. [72] reported the effects of four trimethoxy flavones in paclitaxel-induced peripheral neuropathy in mice. The flavones dose-dependently attenuated paclitaxel-induced tactile allodynia, cold allodynia and thermal hyperalgesia in mice. Flavones dose-dependently inhibited the expression of TNF $\alpha$ and IL-1 $\beta$ with $\mathrm{IC}_{50}$ values ranged from $60.13 \mu \mathrm{M}$, to $90.82 \mu \mathrm{M}$ and $33-72$ $\mu \mathrm{M}$, respectively. Moreover, the flavones dose-dependently decreased 2,2-diphenyl-1-picrylhydrazyl (DPPH) free radicals with $\mathrm{IC}_{50}$ values ranging from 58.82-61.21 $\mu \mathrm{M}$. The $\mathrm{NO}$ generation was also inhibited by the flavones with $\mathrm{IC}_{50}$ ranging from 32.39-74.59 $\mu \mathrm{M}$ [72]. Li et al. [76] reported that methoxy-substituted flavones have a better bioavailability than hydroxy flavones. Therefore, the antinociceptive activities of trimethoxy flavones against paclitaxel-induced peripheral neuropathy could be attributed to the structure-activity relationship of flavonoids, which might enhance their antinociceptive properties. In a similar study, flavonol and its dimethoxy derivatives does-dependently attenuated paclitaxel-induced tactile allodynia, cold allodynia and thermal hyperalgesia in mice along with decrease in pro-inflammatory cytokines TNF $\alpha$ and IL-1 $\beta$ and free radicals, such as DPPH and NO in a dose-dependent manner [73]. 
Table 3. Effects of flavonoids on chemotherapy-induced peripheral neuropathy (CIPN).

\begin{tabular}{|c|c|c|c|c|c|}
\hline \multirow[t]{2}{*}{ Flavonoids } & \multirow[t]{2}{*}{ Animals } & \multirow{2}{*}{$\begin{array}{l}\text { Dose } \mathrm{mg} / \mathrm{kg} \text { (Route of } \\
\text { Administration) }\end{array}$} & \multicolumn{2}{|c|}{ Effects/Mechanisms of Action } & \multirow[t]{2}{*}{ Reference } \\
\hline & & & Behavioral Evaluation & Biochemical/Molecular Parameters & \\
\hline Icariin & $\begin{array}{l}\text { Male Sprague } \\
\text { Dawley rats }\end{array}$ & $\begin{array}{l}25,50 \text {, and } 100 \mathrm{mg} / \mathrm{kg} \\
\text { Intrathecal }\end{array}$ & $\begin{array}{l}\downarrow \text { Paclitaxel-induced mechanical } \\
\text { allodynia in long term }\end{array}$ & $\begin{array}{l}\downarrow \text { Paclitaxel-induced increase of TNF- } \alpha \text {, IL-1 } \beta \text {, and } \\
\text { IL-6, astrocytes, NF- } k \text { B (p65) phosphorylation in } \\
\text { spinal cord } \\
\text { Reversed paclitaxel-induced downregulation of } \\
\text { SIRT1 expression and H4 acetylation }\end{array}$ & Gui et al. [74] \\
\hline $\begin{array}{c}7,2^{\prime}, 3^{\prime} \text {-trimethoxy flavone, } \\
7,2^{\prime} 4^{\prime} \text {-trimethoxy flavone, } \\
7,3^{\prime}, 4^{\prime} \text {-trimethoxy flavone and }\end{array}$ & $\begin{array}{l}\text { Swiss albino mice } \\
\text { Either sex }\end{array}$ & $\begin{array}{c}25,50,100 \text { and } 200 \mathrm{mg} / \mathrm{kg} \\
\text { Subcutaneous } \\
20,30,60,120,240 \mu \mathrm{M}-\text { in vitro }\end{array}$ & $\begin{array}{l}\downarrow \text { Paclitaxel-induced tactile allodynia, } \\
\text { cold allodynia and thermal } \\
\text { hyperalgesia }\end{array}$ & $\begin{array}{l}\text { X Proinflammatory cytokines (TNF } \alpha, \text { IL-1 } 1 \beta) \text { and } \\
\text { free radicals (DPPH, NO) }\end{array}$ & Nadipelly et al. [72] \\
\hline 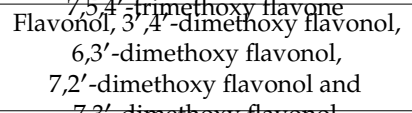 & $\begin{array}{l}\text { Male Swiss albino } \\
\text { mice }\end{array}$ & $\begin{array}{c}25,50,100, \text { and } 200 \mathrm{mg} / \mathrm{kg} \\
\text { Subcutaneous } \\
20,30,60,120,240 \mu \mathrm{M}-\text { in vitro }\end{array}$ & $\begin{array}{c}\downarrow \text { Tactile allodynia, cold allodynia and } \\
\text { thermal hyperalgesia }\end{array}$ & $\mathrm{X} \mathrm{TNF} \alpha, \mathrm{IL}-1 \beta, \mathrm{DPPH}, \mathrm{NO}$ & Sayeli et al. [73] \\
\hline 6-methoxyflavone & $\begin{array}{l}\text { Male } \\
\text { Sprague-Dawley } \\
\text { rats }\end{array}$ & $\begin{array}{l}25,50 \text { and } 75 \mathrm{mg} / \mathrm{kg} \\
\text { Intraperitoneal }\end{array}$ & $\begin{array}{c}\downarrow \text { Cisplatin-induced mechanical } \\
\text { allodynia and heat hypoalgesia } \\
\text { Elicited no detectable deficit in motor } \\
\text { control }\end{array}$ & - & Shahid et al. [69] \\
\hline Quercetin & $\begin{array}{l}\text { Male } \\
\text { Sprague-Dawley } \\
\text { rats and mice }\end{array}$ & $\begin{array}{c}20 \text { and } 60 \mathrm{mg} / \mathrm{kg} \\
\text { Intraperitoneal } \\
3,10,30 \mu \mathrm{M} / \mathrm{L} \text { and } 20 \text { and } 60 \\
\mu \mathrm{M} / \mathrm{L}-\text { in vitro }\end{array}$ & $\begin{array}{c}\uparrow \text { Heat hyperalgesia and mechanical } \\
\text { allodynia in paclitaxel-treated rats and } \\
\text { mice }\end{array}$ & $\begin{array}{c}\downarrow \text { Expressions of PKC } \varepsilon \text { and TRPV1 in spinal cords } \\
\text { and DRGs of paclitaxel-treated rats and mice } \\
\text { X Translocation of PKC } \varepsilon \text { from cytoplasm to } \\
\text { membrane in spinal cord and DRG in } \\
\text { paclitaxel-treated rats and mice } \\
\downarrow \text { Histamine release in RBL-2H3 cells in vitro as } \\
\text { well as in plasma of quercetin-treated rats }\end{array}$ & Gao et al. [71] \\
\hline Naringin & $\begin{array}{l}\text { Wistar rats. Sex } \\
\text { not specified }\end{array}$ & 25,50 , and $100 \mathrm{mg} / \mathrm{kg}$ & $\begin{array}{l}\text { Cisplatin with naringin prevented } \\
\text { behavioral impairment observed in } \\
\text { only cisplatin treated group } \\
\text { X Cisplatin-induced anxiogenic effect } \\
\text { in elevated T-maze test }\end{array}$ & $\begin{array}{c}\text { X Cisplatin-induced increase in } \\
\text { acetylcholinesterase } \\
\downarrow \mathrm{Na}^{+}, \mathrm{K}^{+} \text {-ATPase, } \mathrm{Ca}^{2+} \text {-ATPase, and } \\
\mathrm{Mg}^{2+} \text {-ATPase activities } \\
\text { Altered oxidative biomarkers, antioxidant } \\
\text { enzymes, nonenzymatic antioxidant, increase in } \\
\text { ROS, iNOS mRNA expression, and NO levels in } \\
\text { hippocampus }\end{array}$ & Chtourou et al. [70] \\
\hline $\begin{array}{l}\text { Quercetin, quercetin nanoemulsion, } \\
\text { and rutin }\end{array}$ & Male BALB/c mice & $\begin{array}{c}\text { Quercetin, quercetin } \\
\text { nanoemulsion, and rutin }(20 \\
\mathrm{mg} / \mathrm{kg}) \\
\text { Oral gavage }\end{array}$ & $\begin{array}{l}\downarrow \text { Oxaliplatin-induced mechanical } \\
\text { allodynia }\end{array}$ & $\begin{array}{l}\downarrow \text { Nociceptive biomarker c-Fos in dorsal horn of } \\
\text { spinal cord }\end{array}$ & Schwingel et al. [68] \\
\hline Quercetin and rutin & Male Swiss mice & $\begin{array}{c}\text { Rutin and quercetin }(25,50 \text {, and } \\
100 \mathrm{mg} / \mathrm{kg}) \\
\text { Intraperitoneal }\end{array}$ & $\begin{array}{l}\text { X Oxaliplatin-induced peripheral } \\
\text { neuropathy }\end{array}$ & $\begin{array}{l}X \text { Lipid peroxidation, tyrosine nitrosylation, and } \\
\text { peroxynitrite-associated neuronal damage }\end{array}$ & Azevedo et al. [67] \\
\hline
\end{tabular}

$\uparrow=$ Increased, $\downarrow=$ Attenuated/Decreased/Reduced/Suppressed, X = Inhibited/Prevented. 
In summary, flavonoids have inhibited CIPN by attenuating pain behaviors along with inhibiting pro-inflammatory biomarkers as well as pronociceptive signaling pathways and downstream effectors. Flavonoids can be used in attenuating CIPN.

\section{Diabetic Painful Neuropathy}

Diabetic neuropathy is one of the leading causes of neuropathy. According to the International Diabetes Federation, it affects 382 million people worldwide [77]. According to an international meeting on the diagnosis and management of diabetes defined diabetic peripheral neuropathy as "the presence of symptoms and/or signs of peripheral nerve dysfunction in people with diabetes after the exclusion of other causes" [77]. Patients with diabetic neuropathy are characterized with burning, excruciating stabbing kind of pain, numbness, tingling sensation, and might also be associated with paraesthesia and hyperesthesia coupled with the aching of feet or hands [78,79].

Metabolic and vascular are the two major factors for the pathogenesis of diabetic neuropathy. Hyperglycemia leads to the accumulation of fructose and sorbitol due to increased activity of enzyme aldose reductase that confers the rate limiting step in polyol pathway. Hyperglycemia also results in the disturbance of several metabolic pathways, such as advanced glycation end products (AGE) [80,81], hexosamine [82], polyol [83,84], protein kinase C (PKC) [85,86], and poly-ADP ribose polymerase (PARP) $[87,88]$ pathways in the nervous system. The pathways contribute in neuronal and axonal injury in diabetic neuropathy as well as increased level of oxidative stress in nervous system of diabetic neuropathy. These above-mentioned pathways also induce the production of ROS through mitochondria. The metabolic pathways and oxidative stress lead to the activation of NF- $\mathrm{kB}$ and specialty protein-1, resulting in neuroinflammation and vascular impairment.

\section{Effects of Flavonoids on Diabetic Painful Neuropathy}

Table 4 reviews the effects of different flavonoids on diabetic painful neuropathy. Catechin [89], luteolin [90], pelargonidin [91], rutin [92], and genistein [93] have been reported to reduce the MDA levels in diabetic animal. MDA has been considered as a primary biomarker for free radical-mediated lipid damage and oxidative stress. The elevated level of MDA has been reported in the serum and other tissues of diabetic patients, impacting the peripheral nerve [94,95].

The flavonoids catechin [89], naringenin [96], morin [97], kaempferol [98], luteolin [90], rutin [92], genistein [93], hesperidin, and fisetin [99] have been shown to decrease the level of ROS by increase the level of different antioxidative enzymes, such as SOD, CAT, reduced glutathione peroxidase (GSH), GPx and glutathione reductase (GR) in different tissues (brain, liver, sciatic nerve) of diabetic animals. Furthermore, luteolin, morin and rutin have shown to increase the expression of nuclear factor-E2-related factor-2 (Nrf2) Nrf2 and its downstream effectors heme oxygenase-1 (HO-1) in nerve tissues of diabetic animals. Nrf-2/HO-1 plays a protective role against oxidative stress-induced damage and neuroinflammation in diabetic animals [100-102]. Kaempferol reduced AGEs and EGCG reduced 8-hydroxy-2-deoxyguanosine (8-OHdG), which is one of the predominant forms of free radical-induced oxidative lesions in mitochondrial and nuclear DNA [103]. Naringenin and genistein increased nerve growth factor (NGF) in sciatic nerves of diabetic animals. NGF plays important role in life maintenance and survival of the neurons. Decline in NGF induces peripheral nerve lesions like axonal atrophy, demyelination, and reduced number of nerve fibers in diabetic patients [104]. Kishore et al. [98] reported that kaempferol reduced the $\mathrm{NO}$ level in diabetic animals. Besides modulating different oxidative stress biomarkers, flavonoids morin, puerin and rutin reduced the expression of NF- $\mathrm{BB}$, and especially morin prevented the phosphorylation of inhibitor kappa kinase (IKK) and thus prevented the translocation and expression of NF- $\mathrm{kB}$. Several flavonoids decreased the levels of proinflammatory cytokines, like tumor necrosis factor-alpha (TNF $\alpha$ ), interleukin-1beta (IL-1 $\beta)$, interleukin-6 (IL-6), and transforming growth factor $\beta$ (TGF- $\beta$ ).

Matrix metalloprotease 9 (MMP-9) plays an important role in neuropathic pain and is associated with neuroinflammation and oxidative stress [105-107]. MMP-9 is activated by ROS produced at the 
site of injury. ROS inhibitor $\mathrm{N}$-acetyl-cysteine suppress has been shown to suppress the expression of MMP-9 and attenuate neuropathic pain [108,109]. Catechin [89] has been shown to reduce the circulatory MMP-9 in diabetic rats.

Diabetic neuropathy in rodents have also been characterized by assessing behavioral markers, which include thermal, mechanical, chemical hyperalgesia, tactile allodynia in sensory large fibers, and sensory motors deficit in large sensory fibers [110]. The neuropathic assessment showed that flavonoids significantly downregulated chemical, mechanical, thermal hyperalgesia and allodynia in diabetic rodents. Several flavonoids, such as naringenin [96], naringin [111], luteolin [90], baicalin [112], pelargonidin [91], rutin [92], hesperidin [113], and fisetin [99], attenuated diabetes-induced thermal hyperalgesia, whereas morin [97], naringenin [96], naringin [111], kaempferol [98], luteolin [90], epigallocatechin gallate [114], and rutin [92] reduced mechanical hyperalgesia. In addition to hyperalgesia, morin [97], baicalein [112], puerarin [115], hesperidin [113], and fisetin [99] reduced mechanical allodynia, whereas, genistein [93] and naringin [111] reduced mechano-tactile allodynia, and luteolin [90] and rutin [92] reduced cold allodynia. Studies have shown that short term diabetes induced thermal, chemical and mechanical hyperalgesia $[116,117]$, whereas long term diabetes induces thermal and mechanical hypoalgesia [118]. Baicalein ameliorated thermal hypoalgesia [119].

Electrophysiological measurements are employed in order to determine the sensory and motor nerve function, which include the assessment of motor and sensory nerve conduction in the tail and sciatic nerve. Sensory nerve conduction velocity (SNCV) is used to determine sensory nerves status in all the parameters measured in nerve conduction studies. SNCV accurately reflects the myelin integrity and axon caliber [120]. SNCV is slowed by the demyelination of the sensory nerve fibers. SNCV and motor nerve conduction velocity (MNCV) are both slow in diabetic animals. The etiology of nerve dysfunction is attributed to both vascular and non-vascular mechanisms [121]. Flavonoids, such as morin [97], rutin [92], hesperidin [113], and baicalein [119] increased both MNCV and SNCV, whereas kaempferol [98] only increased MNCV. Grape seed proanthocyanidins and its metabolites catechin and epicatechin [122] and luteolin [90] improved nerve conduction velocity in the sciatic nerve in diabetic neuropathy. Morin [97] and luteolin [90] improved nerve function by increasing nerve blood flow.

Besides attenuating oxidative stress biomarkers, pro-inflammatory cytokines, behavioral markers, and improving nerve function, flavonoid catechin increased body weight compared to diabetic animals, reduced heart hypertrophy, and reduced diabetic-induced increase in plasma glucose level [89]. Blood glucose level was also reduced by kaempferol [98], rutin [92], naringenin [96], and luteolin [90]. However, EGCG [114] and genistein [93] showed no effects on body weight and blood glucose level compared to diabetic animals. The diabetes induced body weight loss and increased plasma glucose level were ameliorated by naringenin [96]. GSPs improved diabetic parameters emphasizing mainly on LDL, which was improved when compared with diabetic control ones [122].

In conclusion, these different flavonoids can be used as the potential treatments for diabetic neuropathy. Flavonoids attenuate diabetic neuropathy by modulating different diabetic parameters, oxidative stress biomarkers, pro-inflammatory cytokines, behavioral markers, and nerve function in diabetic neuropathy. 
Table 4. Effects of flavonoids on diabetic painful neuropathy (DPN).

\begin{tabular}{|c|c|c|c|c|c|c|}
\hline \multirow[t]{2}{*}{ Flavonoids } & \multirow[t]{2}{*}{ Animals } & \multirow{2}{*}{$\begin{array}{l}\text { Flavonoids (Dose } \\
\mathrm{mg} / \mathrm{kg} \text { and Route of } \\
\text { Administration) }\end{array}$} & \multicolumn{3}{|c|}{ Effects/Mechanisms of Action } & \multirow[t]{2}{*}{ Reference } \\
\hline & & & $\begin{array}{c}\text { Behavioral Evaluation/Other Diabetic } \\
\text { Parameters }\end{array}$ & $\begin{array}{l}\text { Electrophysiological/ } \\
\text { Functional } \\
\text { Evaluation }\end{array}$ & $\begin{array}{l}\text { Histopathological/Biochemical/Molecular } \\
\text { Parameters }\end{array}$ & \\
\hline \multirow[t]{2}{*}{ Catechin } & \multirow[t]{2}{*}{$\begin{array}{l}\text { Male Sprague Dawley } \\
\text { rats }\end{array}$} & $\underset{\mathrm{mg} / \mathrm{kg}}{25 \mathrm{mg} / \mathrm{kg} \text { and } 50}$ & $\begin{array}{l}\uparrow \text { Body weight compared to diabetic } \\
\text { animals }\end{array}$ & \multirow[t]{2}{*}{ - } & $\begin{array}{l}\text { Improved hemodynamic parameters (heart rate, mean } \\
\text { atrial pressure and left ventricular systolic pressure), } \\
\text { oxidative stress parameters (MDA, GSH, CAT, SOD) }\end{array}$ & \multirow[t]{2}{*}{ Addepalli et al. [89 } \\
\hline & & Intraperitoneal & $\begin{array}{l}\downarrow \text { Heart hypertrophy, plasma glucose } \\
\text { levels }\end{array}$ & & $\begin{array}{l}\text { Reversed diabetes-induced neuronal damage and } \\
\text { reduced circulatory MMP-9 }\end{array}$ & \\
\hline \multirow{5}{*}{ Morin } & \multirow{5}{*}{$\begin{array}{c}\text { Male } \\
\text { Sprague-Dawley rats }\end{array}$} & 50 and $100 \mathrm{mg} / \mathrm{kg}$ & \multirow{5}{*}{$\begin{array}{l}\downarrow \text { Mechanical hyperalgesia and } \\
\text { mechanical allodynia }\end{array}$} & \multirow{5}{*}{$\begin{array}{c}\text { Improved } \\
\text { measurement of } \\
\text { MNCV, SNCV, and } \\
\text { nerve blood flow } \\
\text { (NBF) }\end{array}$} & $\uparrow$ Mitochondrial-specific superoxide dismutase 2 & \multirow{5}{*}{ Bachewal et al. [97] } \\
\hline & & Oral gavage & & & $\begin{array}{l}\text { (SOD2) expression in high glucose-treated N2A cells } \\
\downarrow \text { Glucose-induced ROS generation by increasing } \\
\text { expression of Nrf2 and its downstream effectors NQO1 }\end{array}$ & \\
\hline & & & & & $\downarrow$ IKK (ser176/180) phosphorylation, levels of TNF $\alpha$ & \\
\hline & & 10 and 20 & & & and IL-6 & \\
\hline & & $\mu \mathrm{M}-$ In vitro & & & $\begin{array}{c}\text { X Translocation and expression of NF-kB in N2A cells } \\
\downarrow \text { Levels of TNF } \alpha \text { and IL-6 }\end{array}$ & \\
\hline \multirow{6}{*}{$\begin{array}{c}\text { Grape seed } \\
\text { proanthocyanidins } \\
\text { (GSPs) and its } \\
\text { metabolites C } \\
\text { (+)-catechin; EC, } \\
\text { (-)-epicatechin }\end{array}$} & \multirow{6}{*}{$\begin{array}{c}\text { Male } \\
\text { Sprague-Dawley rats }\end{array}$} & $250 \mathrm{mg} / \mathrm{kg}$ & \multirow{6}{*}{$\begin{array}{l}\text { GSPs - Improved diabetic parameters, } \\
\text { especially low-density lipoprotein level }\end{array}$} & \multirow{6}{*}{$\begin{array}{c}\text { GSPs- } \uparrow \text { Nerve } \\
\text { conduction velocity } \\
\text { (NCV) in sciatic/tibial } \\
\text { nerves }\end{array}$} & $\begin{array}{l}\text { GSPs- }-\uparrow \text { Normal mitochondria, endoplasmic reticulum } \\
\text { in sciatic nerves and partially improved myelin sheath }\end{array}$ & \multirow{6}{*}{ Ding et al. [122] } \\
\hline & & Oral & & & $\begin{array}{c}\text { morphology } \\
\text { GSPs } \downarrow \downarrow \mathrm{Free}^{2+} \mathrm{Ca}^{2+} \text { concentrations and ER stress } \\
\text { markers (GRP78, CHOP, phospho-JNK, total JNK and } \\
\text { cleaved caspase-12) }\end{array}$ & \\
\hline & & $(+)$-catechin; EC, & & & GSPs treated cells showed similar cell viability, LDH & \\
\hline & & (-)-epicatechin & & & $\begin{array}{l}\text { release extent, apoptosis/necrosis cell fractions to } \\
\text { treatment with serum treated from halthy rats }\end{array}$ & \\
\hline & & & & & $\mathrm{C}$ and EC-Partially ameliorated cell injury in cells & \\
\hline & & $2.5,5,10 \mu \mathrm{M}$ & & & $\begin{array}{l}\text { treated with serum from diabetic rats } \\
C \text { and } E C-X \text { Cell iniury } \mathrm{Ca}^{2+} \text { overload and } E R \text { stress }\end{array}$ & \\
\hline \multirow{3}{*}{ Kaempferol } & \multirow{3}{*}{ Male Wistar rats } & \multirow{3}{*}{5 and $10 \mathrm{mg} / \mathrm{kg}$} & \multirow{3}{*}{$\begin{array}{c}\downarrow \text { Blood glucose level at the end of the } \\
\text { study (90 days) } \\
\uparrow \text { Diabetes-induced thermal and } \\
\text { mechanical hyperalgesia }\end{array}$} & \multirow{3}{*}{$\begin{array}{l}\uparrow \mathrm{MNCV} \text { compared to } \\
\text { diabetic control rats }\end{array}$} & $\uparrow$ Levels of GSH SOD and thiobarbituric acid reactive & \multirow{3}{*}{ Kishore et al. [98] } \\
\hline & & & & & substances (TBARS) & \\
\hline & & & & & $\downarrow$ NO level, sciatic AGEs, TNF- $\alpha$, TGF- $\beta$ and IL-1 $\beta$ & \\
\hline Baicalin & $\begin{array}{c}\text { Male } \\
\text { Sprague-Dawley rats }\end{array}$ & $\begin{array}{l}10,20, \text { and } 40 \mu \mathrm{g} / \mathrm{kg} \\
\text { Intraperitoneal }\end{array}$ & $\begin{array}{l}\downarrow \text { Diabetes-induced mechanical } \\
\text { allodynia and thermal hyperalgesia }\end{array}$ & ـ & $\begin{array}{c}\downarrow \text { Both mRNA and protein expressions of TRPV1 in } \\
\text { DRG of diabetic rats }\end{array}$ & Li et al. [112] \\
\hline
\end{tabular}


Table 4. Cont.

\begin{tabular}{|c|c|c|c|c|c|c|}
\hline \multirow[t]{2}{*}{ Flavonoids } & \multirow[t]{2}{*}{ Animals } & \multirow{2}{*}{$\begin{array}{l}\text { Flavonoids (Dose } \\
\mathrm{mg} / \mathrm{kg} \text { and Route of } \\
\text { Administration) }\end{array}$} & \multicolumn{3}{|c|}{ Effects/Mechanisms of Action } & \multirow[t]{2}{*}{ Reference } \\
\hline & & & $\begin{array}{c}\text { Behavioral Evaluation/Other Diabetic } \\
\text { Parameters }\end{array}$ & $\begin{array}{l}\text { Electrophysiological/ } \\
\text { Functional } \\
\text { Evaluation }\end{array}$ & $\begin{array}{l}\text { Histopathological/Biochemical/Molecular } \\
\text { Parameters }\end{array}$ & \\
\hline 6-Methoxyflavanone & $\begin{array}{c}\text { Female } \\
\text { Sprague-Dawley rats } \\
\text { and BALB/c mice }\end{array}$ & $\begin{array}{l}10 \text { and } 30 \mathrm{mg} / \mathrm{kg} \\
\text { Intraperitoneal }\end{array}$ & $\begin{array}{c}\text { No acute toxicity in animals ascertained } \\
\text { by a lack of cyanosis, ataxia, convulsions, } \\
\text { writhing or mortality } \\
\downarrow \text { Thermal nociception in } \\
\text { streptozotocin-induced diabetic } \\
\text { neuropathy model at } 30 \text { - and } 60 \text {-min } \\
\text { post-treatment } \\
\text { Elicited anti-allodynic and } \\
\text { anti-vulvodynic effects }\end{array}$ & - & $\begin{array}{l}\text { Thermal antinociception was antagonized by opioid } \\
\text { receptor antagonist naloxone and GABA antagonist } \\
\text { pentylenetetrazole }\end{array}$ & Akbar et al. [123] \\
\hline \multirow[t]{2}{*}{ Rutin } & \multirow[t]{2}{*}{$\begin{array}{c}\text { Male } \\
\text { Sprague-Dawley rats }\end{array}$} & 5,25 , and $50 \mathrm{mg} / \mathrm{kg}$ & $\downarrow$ Plasma glucose level & \multirow[t]{2}{*}{$\begin{array}{l}\uparrow \mathrm{MNCV} \text { and SNCV } \\
\text { in diabetic rats }\end{array}$} & 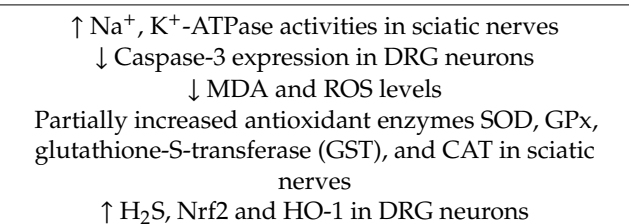 & \multirow[t]{2}{*}{ Tian et al. [92] } \\
\hline & & Intraperitoneal & $\begin{array}{l}\downarrow \text { Diabetes-induced mechanical } \\
\text { hyperalgesia, thermal hyperalgesia, and } \\
\text { cold allodynia }\end{array}$ & & $\begin{array}{c}\downarrow \text { NF-kB, ІкB } \alpha, \text { p-IкB } \alpha, \text { IL-6 and TNF- } \alpha \text { in DRG } \\
\text { neurons of diabetic rats }\end{array}$ & \\
\hline Naringenin & Male Wister albino & 25 and $50 \mathrm{mg} / \mathrm{kg} /$ day & $\begin{array}{l}\text { X Fasting blood glucose level and high } \\
\text { dose of naringenin increased insulin } \\
\text { level }\end{array}$ & - & $\begin{array}{c}\downarrow \text { TNF } \alpha \text {, IL-1 } 1 \beta \text { and IL-6, NO level } \\
\downarrow \text { Elevated TBARS in sciatic nerves } \\
\uparrow \text { GSH, SOD, CAT, GPx and GR levels in sciatic nerves } \\
\text { Improved decreased sciatic expressions of insulin } \\
\text { growth factor and NGF levels in sciatic nerves } \\
\text { In histological analyses, low dose-partial focal } \\
\text { peripheral axonal loss and regenerating thin } \\
\text { myelinated axons, indicative of mild degenerative and } \\
\text { regenerative neuropathy high dose-minimal axonal } \\
\text { degenerative changes without regenerative features, } \\
\text { indicative of minor degenerative neuropathy }\end{array}$ & Al-Rejaie et al. [96] \\
\hline Luteolin & $\begin{array}{c}\text { Male } \\
\text { Sprague-Dawley rats }\end{array}$ & $\begin{array}{l}50 \mathrm{mg} / \mathrm{kg}, 100 \mathrm{mg} / \mathrm{kg} \\
\text { and } 200 \mathrm{mg} / \mathrm{kg} \\
\text { Intraperitoneal }\end{array}$ & $\begin{array}{l}\downarrow \downarrow \text { Plasma glucose levels } \\
\downarrow \text { Diabetes-induced cold allodynia and } \\
\text { mechanical and thermal hyperalgesia }\end{array}$ & $\begin{array}{l}\text { Improved nerve } \\
\text { function by increasing } \\
\text { nerve blood flow } \\
\text { (NBF) and nerve } \\
\end{array}$ & $\begin{array}{l}\qquad \text { ROS and MDA levels } \\
\uparrow \text { Antioxidant enzymes SOD, GST, GPx and CAT along } \\
\text { with Nrf2 and HO- } 1 \text { in nerve tissues in diabetic rats }\end{array}$ & Li et al. [90] \\
\hline $\begin{array}{l}\text { Epigallocatechin-gallate } \\
\text { (EGCG) }\end{array}$ & Male Wistar rats & Oral gavage & $\begin{array}{l}\text { Did not affect blood glucose } \\
\text { concentration, body weight or liquid } \\
\text { intake compared to diabetic animals } \\
\text { Ameliorated diabetes-induced tactile } \\
\text { allodynia and mechanical hyperalgesia }\end{array}$ & $\begin{array}{l}\text { conduction velocity } \\
\text { (NCV) }\end{array}$ & $\begin{array}{l}\text { X Increase of (8-hydroxy-2-deoxyguanosine (8-OHdG) } \\
\text { immunoreaction and Fos expression in spinal cord } \\
\text { X Higher percentage of 8-OHdG-IR cells that } \\
\text { co-localized with Fos }\end{array}$ & Raposo et al. [114] \\
\hline
\end{tabular}


Table 4. Cont.

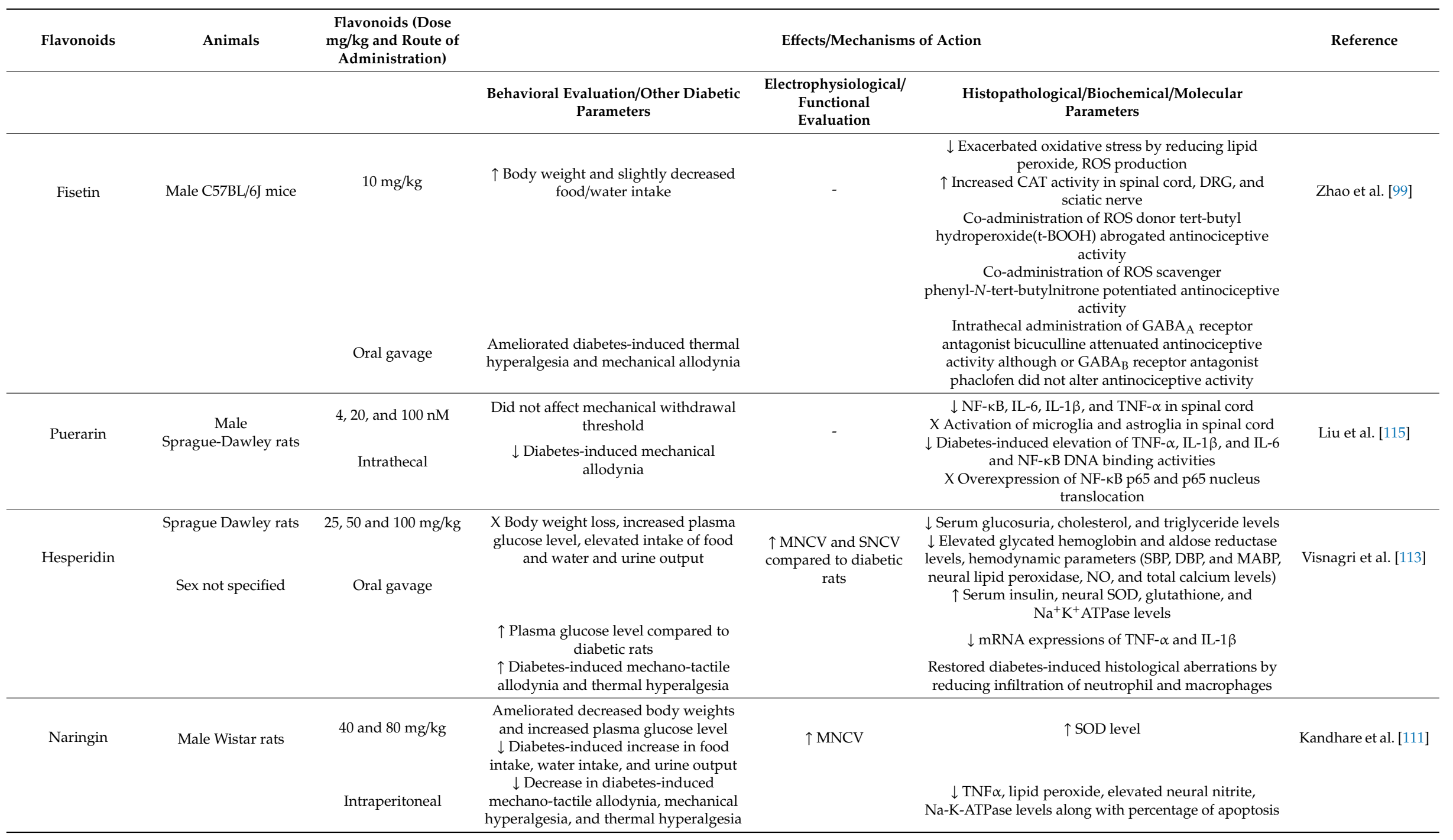


Table 4. Cont.

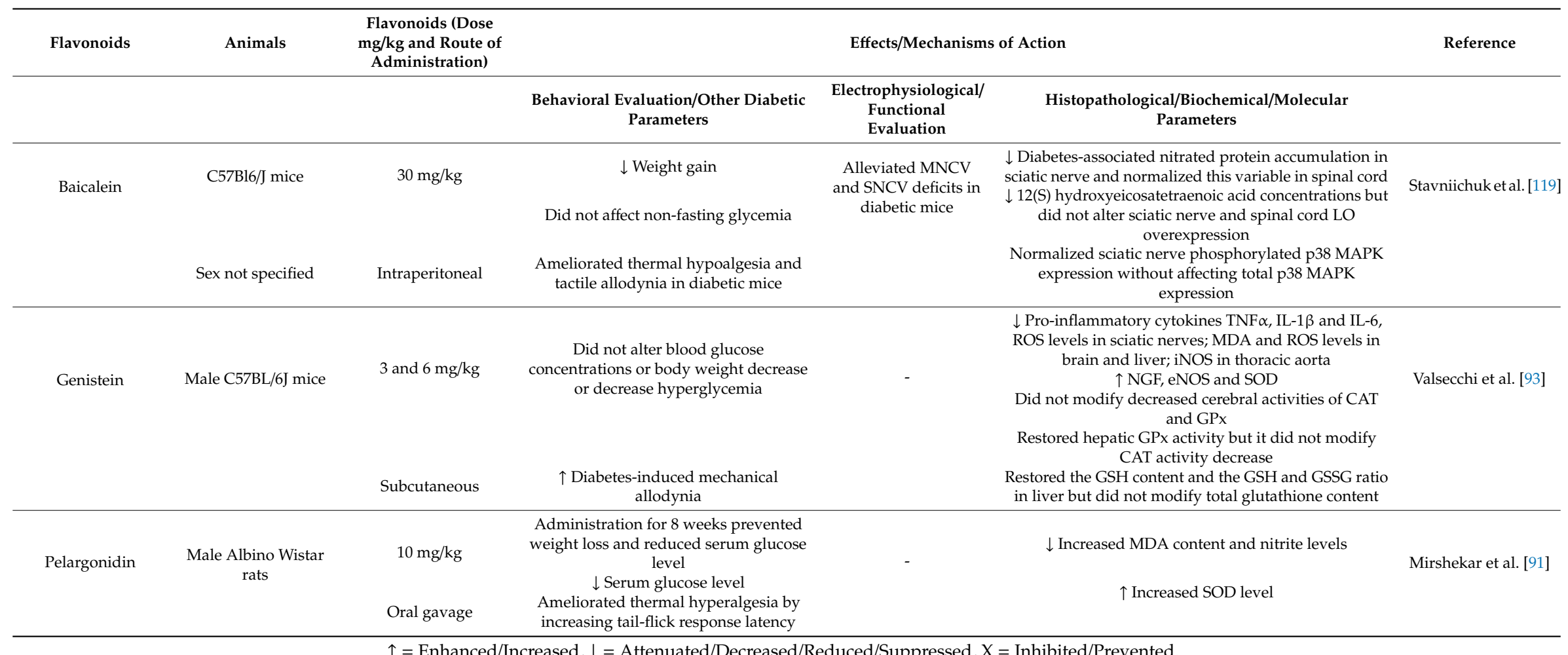

$\uparrow=$ Enhanced/Increased, $\downarrow=$ Attenuated/Decreased/Reduced/Suppressed, $X=$ Inhibited/Prevented. 


\section{Other Peripheral Nerve Injury Models}

Majority of the neuropathic pain models use nerve injury model to induce hyperalgesia and allodynia in rodents. These models represent similarity with human neuropathic pain. Several models in rodents have developed with a mixture of intact and injured peripheral nerve fibers. Moreover, different types of nerve lesions, such as crush, complete or partial tight ligation, loose ligation with inflammatory materials and cryoneurolysis have been employed to study neuropathic pain conditions. The type of nerve lesion determines the character of the ongoing neuropathic pain. The following section of the review will focus on a few peripheral nerve injury models and the effects of flavonoids on those peripheral nerve injury models [124].

\subsection{Sciatic Nerve Chronic Constriction Injury (CCI)}

CCI is one of the most widely studied models for chronic neuropathic pain. The model was first developed by Bennett and Xie [125] and it resembles human neuropathy, resulting from trauma of peripheral nerves with nerve entrapment or compression. The model is produced by exposing the sciatic nerve on one side by making a skin incision and cutting through the connective tissues between the gluteus superficialis and biceps femoris muscles. At 1-mm intervals, four chromic gut ligatures are loosely tied around the sciatic nerves to just obstruct but not prevent the epidural blood flow. The wound is covered by placing sutures in the muscles and staples in the skin [125]. CCI leads to intraneural edema by strangulating the nerve and axotomizing nerve axons. CCI also results in thermal hyperalgesia and mechanical allodynia in mice model of CCI [126].

\subsection{Effects of Flavonoids on Sciatic Nerve CCI Model}

Table 5 summarizes the effects of flavonoids on CCI-induced neuropathic pain. CCI-induced pain includes several symptoms, including spontaneous (tingling, burning, electric-shock like) pain, dysesthesia, paraesthesia, allodynia, and hyperalgesia [127]. Flavonoids diosmin [128], hesperidin [129], and grape seed proanthocyanidins [130] reduced both thermal and mechanical hyperalgesia, whereas isoorientin [131], morin [132], EGCG [133], epigallocatechin derivate compounds 23 and 30 [134], and genistein [135] reduced only thermal hyperalgesia. Quercetin has been reported to reduce thermal and mechanical hypersensitivities in a superior degree compared to gabapentin and morphine [136]. Furthermore, pre-injury administration of quercetin showed long term effects on mechanical hypersensitivity, indicating the antinociceptive effects of quercetin in CCI model [136]. CCI-induced mechanical allodynia has been reduced by isoorientin [131], morin [132], puerarin [115], EGCG [133], and genistein [135]. Isoorientin [131] and morin [132] reduced cold allodynia. Luteolin has been reported to reduce cold and mechanical hyperalgesia, but not thermal hyperalgesia [137]. On the other hand, fisetin reduced thermal hyperalgesia, but not nociceptive sensitivity to mechanical stimuli [99].

In CCI model of neuropathic pain, oxidative/nitrosative stress and antioxidant enzymes (SOD and GSH) play important roles in the neuropathology and behavioral consequences [108,138]. Oxidative/nitrosative stress depletes the antioxidative enzymes and amplifies inflammatory processes in DRG, nerve and spinal $[138,139]$. The antioxidative enzymes SOD and CAT play important roles in balancing between the oxidative and prooxidative systems by scavenging free radicals and preventing peroxidative stress reaction [140]. Studies have shown that systematic injections of antioxidant reduced heat hyperalgesia $[141,142]$. Co-treatment of morphine with grape seed proanthocyanidins (GSPE) increased the levels of GSH, SOD, CAT, nitrate, and decreased MDA level as compared to the individual treatment with morphine or GSPE [130]. Morin restored GSH level and decreased nitrite level in the spinal cord [132] and genistein decreased the levels of ROS and MDA, increased GPx and CAT activities to combat the oxidative stress, as well as normalized nerve-injury-induced inducible nitric oxide synthase (iNOS) and neuronal nitric oxide synthase (nNOS) [135] in CCI model of neuropathic 
pain. Another study showed that isoorientin increased the levels of T-AOC, T-SOD, and CAT, and decreased MDA levels in CCI operated mice [131].

The increased level of nitro oxidative stress leads to the DNA damage, which in turn activates PARP, resulting in PARP-mediated DNA repair by transferring ADP-ribose units to the nuclear proteins. However, PARP activation leads to the activation of NF- $\mathrm{KB}$, which in turn leads to the activation of pro-inflammatory markers, such as cyclooxygenase-2 (COX-2), iNOS, TNF- $\alpha$, and IL-6, playing a major role in pain processing events $[143,144]$. The effects of flavonoids on different pro-inflammatory biomarkers have also been reported in CCI-induced neuropathic pain model [128]. Single treatment of diosmin reduced the mRNA expressions of IL-1 $\beta$, IL-33, and St2, whereas prolonged treatment reduced the mRNA expression of TNF $\alpha$ along with IL-1 $\beta$, IL-33, and St2. On the other hand, a single treatment reduced the expressions of microglia (Iba-1) and oligodendrocytes (Olig2) and prolonged treatment reduced astrocytes (Gfap) along with microglia and oligodendrocytes [128]. Another study showed that puerarin reduced the enhanced immunoreactivity of Iba- 1 and GFAP, which are microglia and astroglia activation marker, respectively [115]. Morin reduced several inflammatory biomarkers (PARP, iNOS, COX-2, NF- $\mathrm{kB}$ and phospho-NF-kB, TNF- $\alpha$ and IL-6) in CCI-induced neuropathic pain model [132]. CCI-induced nerve injury causes the increase in DNA damage, resulting in the overactivation of PARP enzyme [145]. PARP overactivation leads to bioenergetic failure because overaction of PARP consumes a high amount of nicotinamide adenine dinucleotide (NAD) during DNA repair, and finally NAD synthesis consumes ATP, leading to the failure of ATP-dependent biochemical processes [146]. Morin treatment significantly restored CCI-induced depleted ATP levels and recused the neuronal cells from bioenergetic crisis [132]. Kuang et al. [133] reported that EGCG treatment decreased the mRNA and protein expressions of toll-like receptor (TLR4) and its endogenous ligand HMGB1. TLR4 is a pattern recognition receptor and involved in immune and inflammatory disease. Once the endogenous ligand binds to the TL4R, the receptor gets activated and induces the production of pro-inflammatory cytokines via activation of NF-kB $[147,148]$. Moreover, EGCG decreased downstream pro-inflammatory cytokines (IL-1 $\beta$ and TNF- $\alpha$ ) of TLR4 signaling pathway, increased anti-inflammatory cytokine (IL-10), and downregulated NF- $\mathrm{kB}$ expression in lumbar spinal dorsal horn of CCI rats [133]. In another study EGCG and its derivate compound 30 but not compound 23 reduced mRNA and protein expressions of TNF- $\alpha$, IL-1 $\beta$, IL-6 in dorsal horn of spinal cord [134]. Furthermore, EGCG and compound 30 but not compound 23 reduced NF- $\mathrm{kB}$ protein expression in dorsal horn of spinal cord [134]. The treatment of puerarin, and isoorientin also attenuated CCI-induced pro-inflammatory cytokines (TNF- $\alpha$, IL-1 $\beta$, IL-6) $[115,131]$. Genistein also downregulated mRNA expressions of both IL-1 $\beta$ and IL-6 in sciatic nerve and protein expression of IL-1 $\beta$ in DRG and spinal cord [135].

Puerarin attenuated the overexpression of NF- $\mathrm{KB}$ and nuclear translocation of p65 [115], whereas genistein abolished the activation of NF- $\mathrm{KB}$ but did not alter its transcription in the spinal cord [135]. The expression of protein expression of NF- $\mathrm{KB}$ in the dorsal horn of spinal cord was attenuated by EGCG and compound 30 but not compound 23 [134].

Peripheral nerve constriction is commonly associated with loss of sensory function, mainly connected to the nerve fiber structure damage. Zhang et al. [131] reported isoorientin effectively increased the amplitude of SNCV and sensory nerve action potential (SNAP) after CCI surgery, indicating the ameliorative properties of isoorientin in CCI-induced nerve damage. Furthermore, isoorientin showed neuroprotective effects by restoring the disordered arrangement of myelinated nerve fibers, neuronal gaps, axon separation after CCI operation. Isoorientin also reduced the MMP-9 expression as well as overexpressed astrocytes and microglia in CCI operated mice [131]. MMP-9 is required for the activation of glial cell via activating pro-inflammatory cytokines [106,149]. In another study, morin treatment improved sciatic functional index (SFI) but was unable to completely recover to the normal SFI. Furthermore, morin decreased the spontaneous pain behavior and corrected foot deformity by showing no postural deficits [132].

Zhao et al. [99] explored the antinociceptive activity of fisetin, a 3,3' $4^{\prime}, 7$-tetrahydroxyflavone, in a mouse neuropathic pain model after performing sciatic nerve CCI. The study found that fisetin 
exerted antihyperalgesic effect in CCI-induced animals by activating descending monoamine system with markedly increasing spinal monoamine (serotonin) levels and the ratio of 5-HT/5-HTP, and concomitantly decreasing spinal monoamine oxidase A (MAO-A). Furthermore, the study showed antihyperalgesic activity of fisetin was abolished by co-administration of 5-HT7 receptor antagonist (SB-258719), indicating the involvement of 5-HT7 in the fisetin-induced antinociceptive activity. Fisetin also attenuated the co-morbid depressive and anxiety-like behaviors developed following 2-3 weeks CCI surgery, as shown by the increased immobility time in forced swim test, increased latency to feed in novelty suppressed feeding test, and deceased lit compartment time in light-dark test [99]. In another study, the significant antihyperalgesic effect induced by the combination of hesperidin with diosmin was abolished by the presence of naloxone (opioid receptor antagonist), bicuculline $\left(\mathrm{GABA}_{\mathrm{A}}\right.$ receptor antagonist), and haloperidol (D2 receptor antagonist), indicating the involvement of the afore-mentioned receptors in hesperidin-diosmin-induced antihyperalgesia in CCI model of neuropathic pain [129]. In another study, co-treatment of grape seed proanthocyanidins with morphine enhanced the antihyperalgesic activity of morphine and reduced morphine-induced tolerance [130]. Luteolin has also been reported to possess antihyperalgesic effects in the spinal cord via $\gamma$-aminobutyric acid $_{\mathrm{A}}\left(\mathrm{GABA}_{\mathrm{A}}\right)$ and $\mu$-opioid receptors as evident by employing $\mathrm{GABA}_{\mathrm{A}}$ and opioid receptor antagonists bicuculline and naloxone, respectively, but not via benzodiazepine and glycine receptors as evident by the application of benzodiazepine and glycine receptor antagonists, flumazenil and strychnine, respectively. Furthermore, supraspinal administration of luteolin showed no antihyperalgesic effects, indicating that this region is unlikely to contribute in antihyperalgesic effects of luteolin. Moreover, only high concentration of luteolin inhibited motor function, evident in rotarod latency experiment [137]. In another study, by employing inhibitors for NOS (L-NAME), soluble guanylate cyclase (ODQ), PKG (KT5823), and ATP sensitive potassium $\mathrm{K}^{+}$channels, diosmin has been reported to inhibit CCI-induced thermal and mechanical hyperalgesia by activating NO/cGMP/PKG/KATP channel signaling pathway [128]. Valsecchi et al. [135] reported that the antinociceptive activities of genistein was mediated by ER $\beta$ because the treatment with ER $\beta$-specific antagonist PHTPP abrogated its antinociceptive activities. The involvement of ER $\beta$ in attenuating CCI-induced neuropathic pain could be explained by the greater affinity of genistein towards ER $\beta$ than $\mathrm{ER} \alpha$ [150]. The neuropathic pain is also induced by the enhancement of $N$-methyl-D-aspartate receptor (NMDAR) through the expression of NMDAR2B subunit in the dorsal horn of spinal cord [151]. Xifró et al. [134] reported the involvement of NMDAR in CCI-induced neuropathic pain in which EGCG derivative compound 30 but not EGCG and another compound 23 reduced phosphorylation and protein expression of NMDAR receptor subunit NMDAR2B in the dorsal horn of the spinal cord. Xifró et al. [134] also reported that EGCG and compound 30 but not compound 23 reduced fatty acid synthase activity (FASN) in dorsal horn of spinal cord. Although, EGCG and compounds 23 and 30 showed no effects on FASN protein expression. FASN has been well reported to play important role in neuropathic pain followed by peripheral nerve injuries [152-154].

\subsection{Partial Sciatic Nerve Injury (PNI)}

The partial sciatic nerve ligation model is created by ligating the dorsal third to half of the common sciatic nerve at the upper-thigh level [155]. Briefly, the left hind leg of rat is shaved and dissected to expose the sciatic nerve at the upper-thigh level. Using 8-0 silk suture, the dorsal one-third to sciatic nerve is tightly ligated just distal to the point at which thr posterior biceps semitendinosus nerve branches off [155]. A similar model developed by Malmberg and Basbaum [156] also used to study neuropathic pain and development of new therapeutics [157-160]. 
Table 5. Effects of flavonoids on sciatic nerve chronic constriction injury (CCI).

\begin{tabular}{|c|c|c|c|c|c|c|}
\hline \multirow[t]{2}{*}{ Flavonoids } & \multirow[t]{2}{*}{ Animals } & \multirow{2}{*}{$\begin{array}{l}\text { Flavonoids (Dose } \\
\mathrm{mg} / \mathrm{kg} \text { and Route of } \\
\text { Administration) }\end{array}$} & \multicolumn{3}{|c|}{ Effects/Mechanisms of Action } & \multirow[t]{2}{*}{ Reference } \\
\hline & & & $\begin{array}{l}\text { Behavioral Evaluation/Other } \\
\text { CCI-Induced Parameters }\end{array}$ & $\begin{array}{l}\text { Electrophysiological/ } \\
\text { Functional } \\
\text { Evaluation }\end{array}$ & $\begin{array}{l}\text { Histopathological/Biochemical/Molecular } \\
\text { Parameters }\end{array}$ & \\
\hline Isoorientin & $\begin{array}{l}\text { Male pathogen-free } \\
\text { Institute of Cancer } \\
\text { Research (ICR) mice }\end{array}$ & $\begin{array}{c}7.5,15 \text {, and } 30 \mathrm{mg} / \mathrm{kg} \\
\text { Intragastrical }\end{array}$ & $\begin{array}{l}\downarrow \text { CCI-induced mechanical and cold } \\
\text { allodynia and thermal hyperalgesia }\end{array}$ & $\begin{array}{l}\text { Restored } \\
\text { CCI-induced } \\
\text { SNCV and SNAP }\end{array}$ & 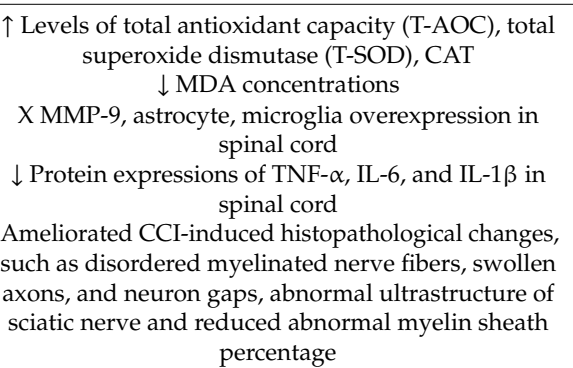 & Zhang et al. [131] \\
\hline Diosmin & Male Swiss mice & $\begin{array}{c}1,10 \mathrm{mg} / \mathrm{kg} \\
\text { Intraperitoneal }\end{array}$ & $\begin{array}{l}\text { X CCI-induced mechanical and } \\
\text { thermal hyperalgesia by } \\
\text { NO/cGMP/PKG/KATP channel } \\
\text { signaling pathway }\end{array}$ & P & $\begin{array}{l}\text { Single treatment-X mRNA expressions of spinal } \\
\text { cord cytokine (IL-1 } \beta \text {, IL-33, St2) } \\
\text { Prolonged treatment- } \downarrow \text { TNF } \alpha \text { mRNA expression in } \\
\text { spinal cord } \\
\text { Single treatment-X Glial cells activation microglia } \\
\text { (Iba- }-1 \text { ), oligodendrocytes (Olig2) } \\
\text { Prolonged treatment-X (Gfap), Iba- }-1 \text {, and Olig2 } \\
\text { mRNA expressions }\end{array}$ & Bertozzi et al. [128] \\
\hline $\begin{array}{l}\text { Diosmin and } \\
\text { Hesperidin }\end{array}$ & Male Wistar rats & $\begin{array}{l}\text { Hesperidin }(10,100, \\
316.2,562.3,1000 \\
\mathrm{mg} / \mathrm{kg}), \mathrm{Diosmin}(10, \\
100 \mathrm{mg} / \mathrm{kg}) \\
\text { Intraperitoneal }\end{array}$ & $\begin{array}{l}\text { Hesperidin }-\downarrow \text { Mechanical and } \\
\text { thermal hyperalgesia } \\
\text { Hesperidin + Diosmin - Improved } \\
\text { antihyperalgesic activity }\end{array}$ & c & $\begin{array}{c}\text { Combined antihyperalgesic activity mediated by D2, } \\
\text { GABA }_{A} \text {, and opioids receptors, but not 5-HT1A } \\
\text { receptor }\end{array}$ & Carballo-Villalobos et al. [129] \\
\hline Quercetin & Male Wistar rats & $100 \mathrm{mg} / \mathrm{kg}$ & $\begin{array}{l}\text { Alleviated mechanical and thermal } \\
\text { hypersensitivity higher than } \\
\text { morphine and gabapentin } \\
\text { Pre-injury administration showed } \\
\text { long-term effects on mechanical } \\
\text { hypersensitivity }\end{array}$ & - & - & Çivi et al. [136] \\
\hline $\begin{array}{c}\text { Grape seed } \\
\text { Proanthocyanidins } \\
\text { (GSPE) }\end{array}$ & Either sex & 100 and $200 \mathrm{mg} / \mathrm{kg}$ & $\begin{array}{l}\downarrow \text { Mechanical and thermal } \\
\text { hyperalgesia }\end{array}$ & - & $\begin{array}{c}\downarrow \text { MDA and nitrate levels in sciatic nerves } \\
\text { Co-treatment of GSPE and morphine attenuated } \\
\text { morphine tolerance, enhanced antihyperalgesic } \\
\text { activity } \\
\uparrow \text { GSH level, SOD, and CAT compared to } \\
\text { GSPE-alone- and morphine-alone treatments }\end{array}$ & Kaur et al. [130] \\
\hline
\end{tabular}


Table 5. Cont.

\begin{tabular}{|c|c|c|c|c|c|c|}
\hline \multirow[t]{2}{*}{ Flavonoids } & \multirow[t]{2}{*}{ Animals } & \multirow{2}{*}{$\begin{array}{l}\text { Flavonoids (Dose } \\
\text { mg/kg and Route of } \\
\text { Administration) }\end{array}$} & \multicolumn{3}{|c|}{ Effects/Mechanisms of Action } & \multirow[t]{2}{*}{ Reference } \\
\hline & & & $\begin{array}{l}\text { Behavioral Evaluation/Other } \\
\text { CCI-Induced Parameters }\end{array}$ & $\begin{array}{l}\text { Electrophysiological/ } \\
\text { Functional } \\
\text { Evaluation }\end{array}$ & $\begin{array}{c}\text { Histopathological/Biochemical/Molecular } \\
\text { Parameters }\end{array}$ & \\
\hline Morin & $\begin{array}{c}\text { Male } \\
\text { Sprague-Dawley rats }\end{array}$ & $\begin{array}{c}15 \text { and } 30 \mathrm{mg} / \mathrm{kg} \\
\text { Oral gavage }\end{array}$ & $\begin{array}{c}\text { Improved CCI-induced thermal } \\
\text { hyperalgesia, mechanical and cold } \\
\text { allodynia } \\
\downarrow \text { Spontaneous pain, corrected foot } \\
\text { deformity }\end{array}$ & $\begin{array}{l}\text { Improved SFI but } \\
\text { did not } \\
\text { completely } \\
\text { recover to normal } \\
\text { SFI }\end{array}$ & $\begin{array}{c}\text { Restored levels of GSH, ATP } \\
\downarrow \text { Nitrite levels in spinal cord } \\
\downarrow \text { Inflammatory markers (PARP, iNOS, COX-2, NF- } \mathrm{kB} \\
\text { and phospho-NF-kB, TNF- } \alpha \text { and IL-6) in spinal cord } \\
\downarrow \text { poly (ADP) ribose (PAR) and NF-kB levels }\end{array}$ & Komirishett et al. [132] \\
\hline $\begin{array}{l}\text { EGCG and its two } \\
\text { synthetic derivative } \\
\text { compounds } 23 \text { and } 30\end{array}$ & Female Balb-c mice & $\begin{array}{l}10,30,50 \text { and } 100 \\
\mathrm{mg} / \mathrm{kg} \\
\text { Intraperitoneal }\end{array}$ & $\begin{array}{l}\text { EGCG and compound } 30 \text { but not } \\
\text { compound } 23-\downarrow \text { CCI-induced } \\
\text { thermal hyperalgesia }\end{array}$ & 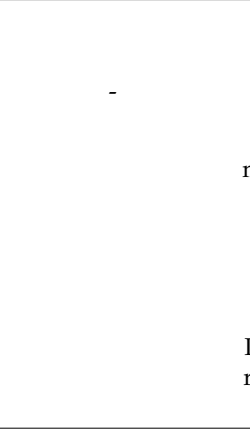 & 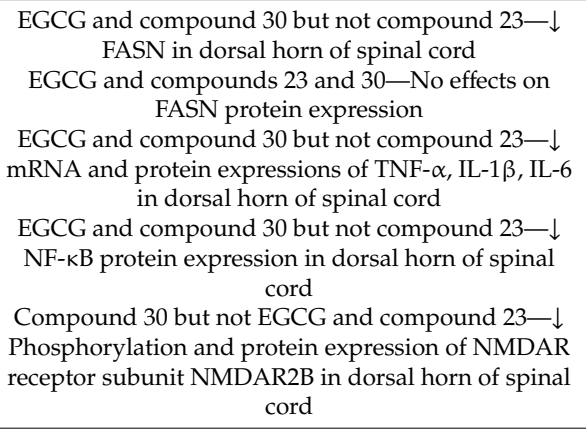 & Xifró et al. [134] \\
\hline Fisetin & Male C57BL/6J mice & $\begin{array}{c}5,15 \text { and } 45 \mathrm{mg} / \mathrm{kg} \\
\text { Oral gavage }\end{array}$ & $\begin{array}{l}\downarrow \text { CCI-induced thermal hyperalgesia } \\
\text { but not nociceptive sensitivity to } \\
\text { mechanical stimuli } \\
\downarrow \text { CCI-induced co-morbid depressive } \\
\text { and anxiety-like behaviors }\end{array}$ & $\downarrow$ & $\begin{array}{l}\downarrow \text { Escalated MAO-A to level like non-injured animals } \\
\text { but did not affect MAO-B in sham or CCI mice } \\
\text { Exhibited antinociceptive activity with involvement } \\
\text { of serotonergic system (coupled with 5-HT7) }\end{array}$ & Zhao et al. [99] \\
\hline Luteolin & $\begin{array}{c}\text { Male } \\
\text { Sprague-Dawley rats }\end{array}$ & $\begin{array}{l}\text { Intrathecal or } \\
\text { intracerebroventricular }\end{array}$ & $\begin{array}{l}\text { Spinal administration reduced cold } \\
\text { and mechanical, but not thermal } \\
\text { hyperalgesia by activating GABA } \mathrm{A}_{\mathrm{A}} \\
\text { receptors in a flumazenil-insensitive } \\
\text { manner and } \mu \text {-opioid receptor } \\
\text { Supraspinal administration showed } \\
\text { no antihyperalgesic activity } \\
\text { High concentration inhibited motor } \\
\text { function }\end{array}$ & - & - & Hara et al. [137] \\
\hline Puerarin & $\begin{array}{c}\text { Male } \\
\text { Sprague-Dawley rats }\end{array}$ & $\begin{array}{l}\text { 4, 20, and } 100 \mathrm{nM} \\
\text { Intrathecal }\end{array}$ & $\downarrow$ CCI-induced mechanical allodynia & - & $\begin{array}{l}\text { X Activation of microglia and astroglia in spinal } \\
\text { dorsal horn } \\
\downarrow \text { TNF- } \alpha \text {, IL-1 } \beta \text {, IL-6, DNA binding activities, } \\
\text { overexpression of NF-kB as well as nuclear } \\
\text { translocation of p65 }\end{array}$ & Liu et al. [115] \\
\hline
\end{tabular}


Table 5. Cont.

\begin{tabular}{|c|c|c|c|c|c|c|}
\hline \multirow[t]{2}{*}{ Flavonoids } & \multirow[t]{2}{*}{ Animals } & \multirow{2}{*}{$\begin{array}{c}\text { Flavonoids (Dose } \\
\text { mg/kg and Route of } \\
\text { Administration) }\end{array}$} & \multicolumn{3}{|c|}{ Effects/Mechanisms of Action } & \multirow[t]{2}{*}{ Reference } \\
\hline & & & $\begin{array}{l}\text { Behavioral Evaluation/Other } \\
\text { CCI-Induced Parameters }\end{array}$ & $\begin{array}{l}\text { Electrophysiological/ } \\
\text { Functional } \\
\text { Evaluation }\end{array}$ & $\begin{array}{l}\text { Histopathological/Biochemical/Molecular } \\
\text { Parameters }\end{array}$ & \\
\hline EGCG & $\begin{array}{c}\text { Male } \\
\text { Sprague-Dawley rats }\end{array}$ & $\begin{array}{l}1 \mathrm{mg} / \mathrm{kg} \\
\text { Intrathecal }\end{array}$ & $\begin{array}{l}\text { Improved CCI-induced mechanical } \\
\text { allodynia and thermal hyperalgesia }\end{array}$ & - & $\begin{array}{c}\downarrow \text { IL-1 } \beta \text { and TNF- } \alpha \\
\uparrow \text { Anti-inflammatory cytokine (IL-10) } \\
\downarrow \text { mRNA and protein expressions of TLR4 and } \\
\text { HMGB1 } \\
\downarrow \text { NF- } k B \text { expression in lumbar spinal dorsal horn }\end{array}$ & Kuang et al. [133] \\
\hline Genistein & Male C57BL/6J mice & $\begin{array}{c}\text { 1,3, } 7.5,15, \text { and } 30 \\
\mathrm{mg} / \mathrm{kg}\end{array}$ & $\begin{array}{l}\text { Reversed CCI-induced thermal } \\
\text { hyperalgesia and mechanical } \\
\text { allodynia }\end{array}$ & $\begin{array}{l}\downarrow \\
\perp\end{array}$ & $\begin{array}{l}\text { mRNA expressions of both IL- } 1 \beta \text { and IL- } 6 \text { in sciatic } \\
\text { nerve and protein expression of IL- } 1 \beta \text { in DRG and } \\
\text { spinal cord } \\
\qquad \text { ROS and MDA levels } \\
\uparrow \text { GPX and CAT activities in CCI operated animals } \\
\text { X NF- } \mathrm{kB} \text { activation but did not modify NF } \\
\text { transcription in spinal cord } \\
\text { Normalized nerved injury-induced increase of iNOS } \\
\text { and nNOS }\end{array}$ & Valsecchi et al. [135] \\
\hline
\end{tabular}

$\uparrow=$ Enhanced/Increased, $\downarrow=$ Attenuated/Decreased/Downregulated/Reduced/Suppressed, $\mathrm{X}=$ Abolished/Inhibited/Prevented. 


\subsection{Spared Nerve Injury (SNI)}

The SNI model involves selective injury of two (peroneal and tibial nerves) of the three terminal branches of the sciatic nerve, leaving the third branch (sural nerve) intact [161]. The model produced pain hypersensitivity in the territory of spared sural nerve, which is similar to the stimulus-evoked pain observed in clinical neuropathic pain syndromes [161,162].

\subsection{Spinal Nerve Ligation (SNL)}

The SNL model consists of unilateral and tight ligation of L5 and/or L6 spinal nerves of rodents at a distal location of dorsal root ganglia. The SNI model simulates human causalgia and was developed by Kim and Chung [163]. SNI model leads to increased sensitivity to heat and other non-painful mechanical stimuli [164]. Furthermore, allodynia and hyperalgesia develop quick after ligation and persist for at least four months exhibiting spontaneous pain behaviors, like guarding, licking, and lifting of the ipsilateral hind paw, but without autotomy behavior The ligation of L5/L6 spinal nerve ligation was developed by Kiso et al. and is useful in studying neuropathic pain [165]. The mechanical allodynia begins at day 1 and lasts for two months post-surgery in the L5/L6 spinal nerve ligation model.

\subsection{Effects of Flavonoids on Other Peripheral Neuropathic Pain Models}

Table 6 summarizes the effect of flavonoids on other peripheral neuropathic pain models. SNL-induced mechanical allodynia has been reduced by baicalein [166], EGCG [167], and myricetin [168]. Baicalein [166] and myricetin [168] attenuated SNL-induced thermal hyperalgesia, whereas quercetin attenuated both thermal and cold hyperalgesia in SNL rats [169]. Moreover, pre-administration of quercetin attenuated neuropathic symptoms [169]. In addition to inhibiting neuropathic pain behavior in SNL rats, quercetin inhibited inflammatory response by inhibiting pro-inflammatory cytokines TNF- $\alpha$ and IL-1 $\beta$ and reduced CCL-2 and MMPs [169], which play important roles in the pathogenesis of neuropathic pain $[105,170]$. The study further confirmed that quercetin inhibited TLR signaling pathway and NF- $\mathrm{kB}$ through activating transforming growth factor- $\beta$-activated kinase (TAK-1) [169]. Baicalein has been reported to reverse global histone-H3 acetylation and suppress HDAC1 expression [166]. Histone acetylation is catalyzed by histone acetyltransferases and removed by histone deacetylases (HDACs) [171]. Studies have shown that pharmacological intervention on the process of histone acetylation can affect pain behavior. Systematic and intrathecal administration of HDAC inhibitors provide analgesic effects in inflammatory pain models, indicating that inhibition of histone acetylation might be useful in pain management $[172,173]$. EGCG has been reported to completely block the neuronal NOS (nNOS) expression, but it failed to inhibit iNOS expression in SNL-induced animals [167]. Both nNOS and iNOS play important roles in mechanical hypersensitivity after peripheral nerve injury and NOS inhibitors reverse or reduce mechanical allodynia and thermal hyperalgesia in neuropathic pain $[160,174]$. Neuronal NOS (nNOS) is predominantly found in central nervous system and is constitutively expressed and activated by calcium signals and iNOS is activated by the pro-inflammatory cytokines and is calcium-independent [175-177]. Hagenacker et al. [168] reported that myricetin at low concentrations reduced voltage activated calcium channel currents $\left(\mathrm{ICa}_{(\mathrm{V})}\right)$. The reduction was abolished by blocking with a PKC inhibitor chelerythrine but not by a p38 inhibitor SB203580. In contrast, high concentrations of myricetin increased voltage activated calcium channel currents $\left(\mathrm{ICa}_{(\mathrm{V})}\right)$ in vitro mediated by p38 but not by PKC. 
Table 6. Effects of flavonoids on other peripheral neuropathic pain models.

\begin{tabular}{|c|c|c|c|c|c|c|}
\hline Flavonoids & Animals & $\begin{array}{c}\text { Flavonoids (Dose } \\
\text { mg/kg and Route } \\
\text { of Administration) }\end{array}$ & \multicolumn{3}{|c|}{ Effects/Mechanisms of Action } & \multirow[t]{2}{*}{ Reference } \\
\hline & & & Behavioral Evaluation & Electrophysiological/Functional Evaluation & $\begin{array}{l}\text { Biochemical/Molecular } \\
\text { Parameters }\end{array}$ & \\
\hline \multicolumn{7}{|c|}{ SNI } \\
\hline Quercetin & $\begin{array}{l}\text { Male } \\
\text { Sprague-Dawley } \\
\text { rats }\end{array}$ & $\begin{array}{c}0.1,1 \% \\
\text { Oral gavage }\end{array}$ & $\begin{array}{l}\text { Pre-surgery administration- }-\downarrow \\
\text { Mechanical allodynia } \\
\text { Post-surgery administration-Did } \\
\text { not affect SNI-induced pain }\end{array}$ & - & $\begin{array}{l}\text { X GFAP in satellite glial cells of } \\
\text { ipsilateral L5 DRG }\end{array}$ & Muto et al. [179] \\
\hline \multicolumn{7}{|c|}{ SNL } \\
\hline \multirow[t]{2}{*}{ Quercetin } & $\begin{array}{l}\text { Sprague } \\
\text { Dawley rats }\end{array}$ & $10-100 \mathrm{mg} / \mathrm{kg}$ & $\begin{array}{l}\text { Single or continuous } \\
\text { administration- }-\downarrow \text { SNL-induced } \\
\text { thermal and cold hyperalgesia }\end{array}$ & \multirow[t]{2}{*}{ - } & $\begin{array}{l}\downarrow \text { Phosphorylation of TAK1, IKK } \\
\text { and JNK2 in cultured astrocytes }\end{array}$ & \multirow[t]{2}{*}{ Ji et al. [169] } \\
\hline & $\begin{array}{l}\text { Sex not } \\
\text { specified }\end{array}$ & Oral gavage & $\begin{array}{l}\text { Pre-surgery administration }-\downarrow \\
\text { Neuropathic pain symptoms when } \\
\text { administered }\end{array}$ & & $\begin{array}{l}\text { X NF- activity via TAK1 in } \\
\text { HEK293 cells } \\
\downarrow \text { Protein expressions of TNF- } \alpha \\
\text { and IL-1 } \beta \text {; mRNA expressions of } \\
\text { MMP-9, MMP-2 and CCL2 }\end{array}$ & \\
\hline Baicalin & $\begin{array}{l}\text { Male Wistar } \\
\text { rats }\end{array}$ & $\begin{array}{c}10 \mu \mathrm{g} \\
\text { Intrathecal }\end{array}$ & $\begin{array}{l}\downarrow \text { SNL-induced mechanical } \\
\text { allodynia and thermal } \\
\text { hyperalgesia } \\
\uparrow \text { Antinociceptive activity of } \\
\text { morphine }\end{array}$ & - & $\begin{array}{l}\text { Reversed histone-H3 acetylation } \\
\text { and HDAC1 expression of } \\
\text { SNL-induced spinal cord dorsal } \\
\text { horn }\end{array}$ & Cherng et al. [166] \\
\hline $\begin{array}{l}\text { Epigallocatechin- } \\
\text { 3-gallate }\end{array}$ & $\begin{array}{c}\text { Male Sprague } \\
\text { Dawley rats }\end{array}$ & $\begin{array}{c}10-50 \mathrm{mg} / \mathrm{kg} \\
\text { Intrathecal }\end{array}$ & $\begin{array}{l}\downarrow \text { SNL-induced mechanical } \\
\text { allodynia }\end{array}$ & - & $\begin{array}{l}\mathrm{X} \text { nNOS expression in spinal } \\
\text { cord of SNL rats }\end{array}$ & Choi et al. [167] \\
\hline Myricetin & $\begin{array}{l}\text { Male Wistar } \\
\text { rats }\end{array}$ & $\begin{array}{c}0.1-10 \mathrm{mg} / \mathrm{kg} \\
\text { Intraperitoneal } \\
0.1-5 \mu \mathrm{M} \text { (low) } \\
10-100 \mu \mathrm{M} \\
\text { (high)—In vitro }\end{array}$ & $\begin{array}{l}\downarrow \text { SNL-induced mechanical } \\
\text { allodynia and thermal } \\
\text { hyperalgesia }\end{array}$ & $\begin{array}{c}\text { Low concentrations- } \downarrow \text { Voltage activated calcium channel } \\
\text { currents }\left(\mathrm{I}_{\mathrm{Ca}(\mathrm{V})}\right) \text { in vitro mediated by PKC but not } \mathrm{p} 38 \\
\text { High concentrations- } \uparrow \text { Voltage activated calcium } \\
\text { channel currents }\left(\mathrm{I}_{\mathrm{Ca}(\mathrm{V})}\right) \text { in vitro mediated by p38 but not } \\
\text { PKC }\end{array}$ & - & Hagenacker et al. [168] \\
\hline \multicolumn{7}{|c|}{ Partial sciatic nerve ligation } \\
\hline Hesperetin & Wistar rats & $\begin{array}{l}20,50 \mathrm{mg} / \mathrm{kg} \\
\text { Oral gavage }\end{array}$ & $\begin{array}{l}\downarrow \text { Partial sciatic nerve } \\
\text { ligation-induced mechanical and } \\
\text { thermal hyperalgesia and } \\
\text { mechanical allodynia }\end{array}$ & $\uparrow$ Motor nerve conduction velocity & $\begin{array}{l}\downarrow \text { TNF- } \alpha \text { mRNA expression in } \\
\quad \text { sciatic nerve } \\
\downarrow \text { Different tissue biomarkers, } \\
\text { such as total protein, NO, lipid } \\
\text { peroxidase, IL-1 } \beta \text { and IL-6 }\end{array}$ & $\begin{array}{l}\text { Aswar et al. } \\
2014[178]\end{array}$ \\
\hline
\end{tabular}

$\uparrow=$ Enhanced/Increased, $\downarrow=$ Attenuated/Decreased/Downregulated/Reduced/Suppressed, $X=$ Blocked/Inhibited/Prevented 
Besides SNL, flavonoids quercetin and hesperetin have been reported to reduce SNI and partial sciatic nerve ligation-induced neuropathic pain [178,179]. Muto et al. [179] evaluated the effect of quercetin on SNI model in which administration of quercetin before surgery attenuated mechanical allodynia but post-administration did not show any effect on the SNI-induced pain. Furthermore, quercetin treatment inhibited glial fibrillary acidic protein (GFAP) in satellite glial cells of ipsilateral L5 DRG. Aswar et al. [178] reported that hesperetin attenuated partial sciatic nerve ligation-induced mechanical and thermal hyperalgesia and mechanical allodynia along with downregulation of TNF $\alpha$ mRNA expression in sciatic nerve and different tissue biomarkers, such as total protein, NO, lipid peroxidase, and interleukins IL-1 $\beta$ and IL-6.

\section{Future Directions}

The present review evaluates the antinociceptive effects of flavonoids on different neuropathic pain conditions. The structurally effective flavonoids consist of catechol substructure on either A- or $\mathrm{B}$ - ring, together with the presence of $\mathrm{C} 3 \mathrm{OH}$ group of $\mathrm{C}$-ring along with an oxo group on $\mathrm{C} 4$. The protective effects of flavonoids are enhanced by a double bond in between $\mathrm{C} 2$ and $\mathrm{C} 3$ due to the formation of a planar molecule or increase in the double bond conjugation in the flavonoids [180]. A study on structure-antioxidant activity relationships reported the protective effects of flavones, flavanones, and flavanols isolated from the resinous exudate of Heliotropium sinuratum due to the presence of 3-OH group [181]. The presence of 5-OH together with 4-oxo group contributed to the activity but only in presence of 3-oxo group. However, without 3-oxo group, the 5-OH with 4-oxo group is inactive.

The present review also focuses on the effects of flavonoids in combating oxidative stress either by increasing the levels of antioxidant enzymes or by decreasing the levels of ROS or other oxidative stress biomarkers in different peripheral neuropathic conditions [72,73,89,91-93,96-99,111,114,130-132,135]. Furthermore, studies have demonstrated that the antioxidant properties of flavonoids could be attributed to the increase in phenolic hydroxyls, replacement of $C-3^{\prime}, 4^{\prime}$ positions in the $\mathrm{B}$ ring of flavonoids by hydroxyls, and the presence of a methoxyl group at the ortho position of phenolic hydroxyl [182]. Besides flavonoids, the structure-activity relationships of phytoestrogens and other phytochemicals are also known to enhance the cytotoxic and antiproliferative activities of breast carcinomas [183,184].

Therefore, the antioxidant as well as antineuropathic properties of flavonoids against different peripheral neuropathic pain conditions could be enhanced by modulating the structure-function relationships, mainly by replacing or adding different functional groups to the core flavonoid structures [180]. In addition to structure-activity relationships, future preclinical as well as clinical studies must also explore other mechanisms that may be implicated in the flavonoid-mediated amelioration of different peripheral neuropathic conditions. Future research studies must address the role of flavonoids in models of diabetes and its complications, as well as opioid use and chronic pain, which are of huge public health and economic concern globally.

\section{Overall Conclusions}

The use of conventional analgesics, such as non-steroidal anti-inflammatory drugs, opioids, tricyclic antidepressants, and anti-convulsants are reported to exhibit a wide spectrum of adverse side effects, which limit the use of these drugs in treating neuropathic pain conditions. Hence, the search for alternative therapeutics with less side effects to attenuate peripheral neuropathic pain has led the researchers to identify and synthesize drugs from natural sources. The present review sheds light on the effects of flavonoids in attenuating peripheral neuropathic pain conditions. The data reported in these studies support that flavonoids are effective in attenuating neuropathic pain in different models, such as spared nerve injury, spinal nerve ligation, partial sciatic nerve injury, diabetes-induced neuropathy, chemotherapy-induced neuropathy, CCI, and related models at behavioral, biochemical, electrophysiological, histopathological, and molecular levels. Figure 1 summarizes the effects of flavonoids on peripheral neuropathic conditions based on the studies reported in the present review (Figure 1). 


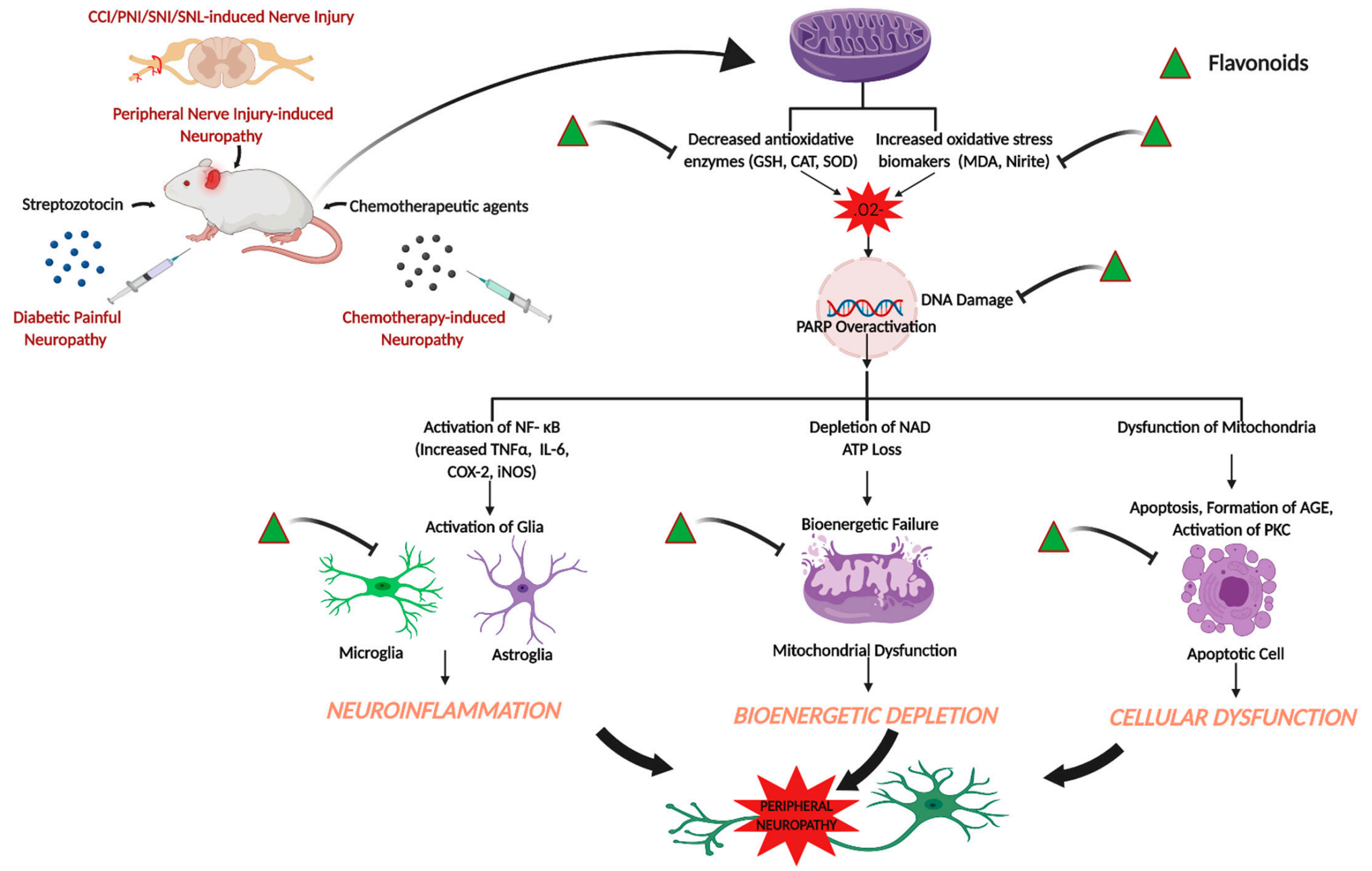

Figure 1. Effects of flavonoids on peripheral neuropathic conditions. Flavonoids attenuate different peripheral neuropathic pain conditions by inhibiting or downregulating different neuroinflammatory, cellular, bioenergetic and oxidative stress markers. The illustration was created with BioRender (http://BioRender.com). 
In conclusion, the present review provides important insights into the effects of flavonoids in alleviating different peripheral neuropathic pain conditions and how each of the flavonoids modulate different pain biomarkers in rodent models of peripheral neuropathy. Thus, there is much potential for the development of flavonoid-based potent neuropathic pain-relieving drugs in future.

Author Contributions: Conceptualization, P.B. and A.B.; methodology, P.B. and A.B.; writing-original draft preparation, P.B.; writing-review and editing, P.B. and A.B. All authors have read and agreed to the published version of the manuscript.

Funding: The authors received no external funding.

Conflicts of Interest: The authors declare no conflict of interest.

\section{References}

1. International Association for the Study of Pain Neuropathic Pain. Available online: https://www.iasp-pain. org/GlobalYear/NeuropathicPain (accessed on 5 March 2020).

2. Gold, M.; Gebhart, G.; Fishman, S. Bonica's Management of Pain; Lippincott Williams \& Wilkins: Philadelphia, PA, USA, 2010; pp. 24-34.

3. Levine, J.D.; Fields, H.L.; Basbaum, A.I. Peptides and the primary afferent nociceptor. J. Neurosci. 1993, 13, 2273-2286. [CrossRef] [PubMed]

4. Pitcher, M.H.; Von Korff, M.; Bushnell, M.C.; Porter, L. Prevalence and Profile of High-Impact Chronic Pain in the United States. J. Pain 2019, 20, 146-160. [CrossRef] [PubMed]

5. Colloca, L.; Ludman, T.; Bouhassira, D.; Baron, R.; Dickenson, A.H.; Yarnitsky, D.; Freeman, R.; Truini, A.; Attal, N.; Finnerup, N.B.; et al. Neuropathic pain. Nat. Rev. Dis Primers 2017, 3, 17002. [CrossRef] [PubMed]

6. van Hecke, O.; Austin, S.K.; Khan, R.A.; Smith, B.H.; Torrance, N. Neuropathic pain in the general population: A systematic review of epidemiological studies. Pain 2014, 155, 654-662. [CrossRef] [PubMed]

7. Abbott, C.A.; Malik, R.A.; van Ross, E.R.; Kulkarni, J.; Boulton, A.J. Prevalence and characteristics of painful diabetic neuropathy in a large community-based diabetic population in the U.K. Diabetes Care 2011, 34, 2220-2224. [CrossRef] [PubMed]

8. Galvez, R.; Rejas, J.; Perez, M.; Gomez, M. [Prevalence of neuropathic pain in Spain: Clinical, working and health care implications]. Med. Clin. (Barc) 2005, 125, 221-229.

9. Freynhagen, R.; Baron, R.; Tolle, T.; Stemmler, E.; Gockel, U.; Stevens, M.; Maier, C. Screening of neuropathic pain components in patients with chronic back pain associated with nerve root compression: A prospective observational pilot study (MIPORT). Curr. Med. Res. Opin. 2006, 22, 529-537. [CrossRef]

10. Kaki, A.M.; El-Yaski, A.Z.; Youseif, E. Identifying Neuropathic Pain among Patients With Chronic Low-Back Pain: Use of the Leeds Assessment of Neuropathic Symptoms and Signs Pain Scale. Reg. Anesth. Amp. Pain Med. 2005, 30, 1-422. [CrossRef]

11. Argoff, C.E.; Cole, B.E.; Fishbain, D.A.; Irving, G.A. Diabetic peripheral neuropathic pain: Clinical and quality-of-life issues. Mayo Clin. Proc. 2006, 81, S3-S11. [CrossRef]

12. Montero, J.H.; Gutierrez-Rivas, E.; Pardo, J.F.; Navarro, C.D. Epidemiological study of prevalence, incidence and neuropathic pain characterization in neurology units. Prevadol study. Neurol. (Barc. Spain) 2005, 20, 385-389.

13. Torrance, N.; Smith, B.H.; Bennett, M.I.; Lee, A.J. The epidemiology of chronic pain of predominantly neuropathic origin. Results from a general population survey. J. Pain 2006, 7, 281-289. [CrossRef] [PubMed]

14. Smith, B.H.; Torrance, N. Epidemiology of neuropathic pain and its impact on quality of life. Curr. Pain Headache Rep. 2012, 16, 191-198. [CrossRef] [PubMed]

15. Meacham, K.; Shepherd, A.; Mohapatra, D.P.; Haroutounian, S. Neuropathic Pain: Central vs. Peripheral Mechanisms. Curr. Pain Headache Rep. 2017, 21, 28. [CrossRef]

16. Harden, R.N. Gabapentin: A new tool in the treatment of neuropathic pain. Acta Neurol. Scand Suppl. 1999, 173, 43-47. [CrossRef]

17. Attal, N. Pharmacologic treatment of neuropathic pain. Acta Neurol. Belg. 2001, 101, 53-64.

18. Finnerup, N.B.; Attal, N.; Haroutounian, S.; McNicol, E.; Baron, R.; Dworkin, R.H.; Gilron, I.; Haanpaa, M.; Hansson, P.; Jensen, T.S.; et al. Pharmacotherapy for neuropathic pain in adults: A systematic review and meta-analysis. Lancet Neurol 2015, 14, 162-173. [CrossRef] 
19. Bril, V.; England, J.; Franklin, G.M.; Backonja, M.; Cohen, J.; Del Toro, D.; Feldman, E.; Iverson, D.J.; Perkins, B.; Russell, J.W.; et al. Rehabilitation, Evidence-based guideline: Treatment of painful diabetic neuropathy: Report of the American Academy of Neurology, the American Association of Neuromuscular and Electrodiagnostic Medicine, and the American Academy of Physical Medicine and Rehabilitation. Neurology 2011, 76, 1758-1765.

20. Ngo, L.T.; Okogun, J.I.; Folk, W.R. 21st century natural product research and drug development and traditional medicines. Nat. Prod. Rep. 2013, 30, 584-592. [CrossRef]

21. da Silva, K.A.B.S.; Manjavachi, M.N.; Paszcuk, A.F.; Pivatto, M.; Viegas, C.; Bolzani, V.S.; Calixto, J.B. Plant derived alkaloid (-)-cassine induces anti-inflammatory and anti-hyperalgesics effects in both acute and chronic inflammatory and neuropathic pain models. Neuropharmacology 2012, 62, 967-977. [CrossRef]

22. Garg, G.; Adams, J.D. Treatment of neuropathic pain with plant medicines. Chin. J. Integr Med. 2012, 18, 565-570. [CrossRef]

23. Liu, M.; Zhou, L.; Chen, Z.; Hu, C. Analgesic effect of iridoid glycosides from Paederia scandens (LOUR.) MERRILL (Rubiaceae) on spared nerve injury rat model of neuropathic pain. Pharm. Biochem. Behav. 2012, 102, 465-470. [CrossRef] [PubMed]

24. Yimam, M.; Brownell, L.; Hodges, M.; Jia, Q. Analgesic effects of a standardized bioflavonoid composition from Scutellaria baicalensis and Acacia catechu. J. Diet. Suppl. 2012, 9, 155-165. [CrossRef] [PubMed]

25. Khoo, H.E.; Azlan, A.; Tang, S.T.; Lim, S.M. Anthocyanidins and anthocyanins: Colored pigments as food, pharmaceutical ingredients, and the potential health benefits. Food Nutr. Res. 2017, 61, 1361779. [CrossRef] [PubMed]

26. McCallum, J.L.; Yang, R.; Young, J.C.; Strommer, J.N.; Tsao, R. Improved high performance liquid chromatographic separation of anthocyanin compounds from grapes using a novel mixed-mode ion-exchange reversed-phase column. J. Chromatogr. A 2007, 1148, 38-45. [CrossRef]

27. Tsao, R.; McCallum, J. Chemistry of Flavonoids. U: Fruit and Vegetable Phytochemicals: Chemistry, Nutritional Value and Stability; Blackwell Publishing: Hoboken, NJ, USA, 2009.

28. Tsao, R.; Yang, R.; Young, J.C.; Zhu, H. Polyphenolic Profiles in Eight Apple Cultivars Using High-Performance Liquid Chromatography (HPLC). J. Agric. Food Chem. 2003, 51, 6347-6353. [CrossRef]

29. Zhao, F.; Watanabe, Y.; Nozawa, H.; Daikonnya, A.; Kondo, K.; Kitanaka, S. Prenylflavonoids and Phloroglucinol Derivatives from Hops (Humulus lupulus). J. Nat. Prod. 2005, 68, 43-49. [CrossRef]

30. Kawaii, S.; Tomono, Y.; Katase, E.; Ogawa, K.; Yano, M. Quantitation of Flavonoid Constituents in Citrus Fruits. J. Agric. Food Chem. 1999, 47, 3565-3571. [CrossRef]

31. Grayer, R.J.; Veitch, N.C. Flavanones and dihydroflavonols. In Flavonoids; CRC Press: Boca Raton, FL, USA, 2005; pp. 924-1009.

32. Manach, C.; Scalbert, A.; Morand, C.; Rémésy, C.; Jiménez, L. Polyphenols: Food sources and bioavailability. Am. J. Clin. Nutr. 2004, 79, 727-747. [CrossRef]

33. Wang, Z.; Wang, D.; Yang, D.; Zhen, W.; Zhang, J.; Peng, S. The effect of icariin on bone metabolism and its potential clinical application. Osteoporos. Int. 2018, 29, 535-544. [CrossRef]

34. Prior, R.L.; Lazarus, S.A.; Cao, G.; Muccitelli, H.; Hammerstone, J.F. Identification of procyanidins and anthocyanins in blueberries and cranberries (Vaccinium spp.) using high-performance liquid chromatography/mass spectrometry. J. Agric. Food Chem. 2001, 49, 1270-1276. [CrossRef]

35. Si, W.; Gong, J.; Tsao, R.; Kalab, M.; Yang, R.; Yin, Y. Bioassay-guided purification and identification of antimicrobial components in Chinese green tea extract. J. Chromatogr. A 2006, 1125, 204-210. [CrossRef] [PubMed]

36. He, F.; Pan, Q.-H.; Shi, Y.; Duan, C.-Q. Chemical synthesis of proanthocyanidins in vitro and their reactions in aging wines. Molecules (Basel Switzerland) 2008, 13, 3007-3032. [CrossRef] [PubMed]

37. Tsao, R. Chemistry and biochemistry of dietary polyphenols. Nutrients 2010, 2, 1231-1246. [CrossRef] [PubMed]

38. Stevens, J.F.; Taylor, A.W.; Deinzer, M.L. Quantitative analysis of xanthohumol and related prenylflavonoids in hops and beer by liquid chromatography-tandem mass spectrometry. J. Chromatogr. A 1999, 832, 97-107. [CrossRef] 
39. Tomás-Barberán, F.A.; Clifford, M.N. Flavanones, chalcones and dihydrochalcones - nature, occurrence and dietary burden. J. Sci. Food Agric. 2000, 80, 1073-1080. [CrossRef]

40. Engelhardt, U.H.; Finger, A.; Kuhr, S. Determination of flavone C-glycosides in tea. Z Lebensm Unters 1993, 197, 239-244. [CrossRef]

41. Carnat, A.; Carnat, A.P.; Fraisse, D.; Ricoux, L.; Lamaison, J.L. The aromatic and polyphenolic composition of Roman camomile tea. Fitoterapia 2004, 75, 32-38. [CrossRef]

42. Caristi, C.; Bellocco, E.; Gargiulli, C.; Toscano, G.; Leuzzi, U. Flavone-di-C-glycosides in citrus juices from Southern Italy. Food Chem. 2006, 95, 431-437. [CrossRef]

43. Wojdyło, A.; Oszmiański, J.; Czemerys, R. Antioxidant activity and phenolic compounds in 32 selected herbs. Food Chem. 2007, 105, 940-949. [CrossRef]

44. Wijaya, G.Y.; Mares, D.J. Apigenin di-C-glycosides (ACG) content and composition in grains of bread wheat (Triticum aestivum) and related species. J. Cereal Sci. 2012, 56, 260-267. [CrossRef]

45. Pereira-Caro, G.; Cros, G.; Yokota, T.; Crozier, A. Phytochemical profiles of black, red, brown, and white rice from the Camargue region of France. J. Agric. Food Chem. 2013, 61, 7976-7986. [CrossRef] [PubMed]

46. Magalhães, S.C.Q.; Taveira, M.; Cabrita, A.R.J.; Fonseca, A.J.M.; Valentão, P.; Andrade, P.B. European marketable grain legume seeds: Further insight into phenolic compounds profiles. Food Chem. 2017, 215, 177-184. [CrossRef] [PubMed]

47. Egert, S.; Rimbach, G. Which sources of flavonoids: Complex diets or dietary supplements? Adv. Nutr. 2011, 2, 8-14. [CrossRef] [PubMed]

48. Ho, H.M.; Chen, R.Y.; Leung, L.K.; Chan, F.L.; Huang, Y.; Chen, Z.-Y. Difference in flavonoid and isoflavone profile between soybean and soy leaf. Biomed. Pharmacother. 2002, 56, 289-295. [CrossRef]

49. Zaheer, K.; Humayoun Akhtar, M. An updated review of dietary isoflavones: Nutrition, processing, bioavailability and impacts on human health. Crit. Rev. Food Sci. Nutr. 2017, 57, 1280-1293. [CrossRef]

50. Bowles, D.; Isayenkova, J.; Lim, E.K.; Poppenberger, B. Glycosyltransferases: Managers of small molecules. Curr. Opin. Plant. Biol. 2005, 8, 254-263. [CrossRef]

51. Ferrer, J.L.; Austin, M.B.; Stewart, C. Jr.; Noel, J.P. Structure and function of enzymes involved in the biosynthesis of phenylpropanoids. Plant. Physiol. Biochem. 2008, 46, 356-370. [CrossRef]

52. Jensen, T.S.; Baron, R.; Haanpaa, M.; Kalso, E.; Loeser, J.D.; Rice, A.S.; Treede, R.D. A new definition of neuropathic pain. Pain 2011, 152, 2204-2205. [CrossRef]

53. O'Connor, A.B. Neuropathic pain: Quality-of-life impact, costs and cost effectiveness of therapy. Pharmacoeconomics 2009, 27, 95-112. [CrossRef]

54. Langley, P.C.; Van Litsenburg, C.; Cappelleri, J.C.; Carroll, D. The burden associated with neuropathic pain in Western Europe. J. Med. Econ. 2013, 16, 85-95. [CrossRef]

55. Yawn, B.P.; Wollan, P.C.; Weingarten, T.N.; Watson, J.C.; Hooten, W.M.; Melton, L.J. 3rd, The prevalence of neuropathic pain: Clinical evaluation compared with screening tools in a community population. Pain Med. 2009, 10, 586-593. [CrossRef] [PubMed]

56. Borsook, D. Neurological diseases and pain. Brain 2012, 135, 320-344. [CrossRef] [PubMed]

57. Watson, J.C.; Sandroni, P. Central Neuropathic Pain Syndromes. Mayo Clin. Proc. 2016, 91, 372-385. [CrossRef] [PubMed]

58. Finnerup, N.B.; Haroutounian, S.; Kamerman, P.; Baron, R.; Bennett, D.L.; Bouhassira, D.; Cruccu, G.; Freeman, R.; Hansson, P.; Nurmikko, T.; et al. Neuropathic pain: An updated grading system for research and clinical practice. Pain 2016, 157, 1599-1606. [CrossRef]

59. Hershman, D.L.; Lacchetti, C.; Dworkin, R.H.; Lavoie Smith, E.M.; Bleeker, J.; Cavaletti, G.; Chauhan, C.; Gavin, P.; Lavino, A.; Lustberg, M.B.; et al. Prevention and management of chemotherapy-induced peripheral neuropathy in survivors of adult cancers: American Society of Clinical Oncology clinical practice guideline. J. Clin. Oncol. 2014, 32, 1941-1967. [CrossRef]

60. Fallon, M.T. Neuropathic pain in cancer. Br. J. Anaesth 2013, 111, 105-111. [CrossRef]

61. Banach, M.; Juranek, J.K.; Zygulska, A.L. Chemotherapy-induced neuropathies-a growing problem for patients and health care providers. Brain Behav. 2017, 7, e00558. [CrossRef]

62. Brown, T.J.; Sedhom, R.; Gupta, A. Chemotherapy-Induced Peripheral Neuropathy. Jama Oncol. 2019, 5, 750. [CrossRef] 
63. Maestri, A.; De Pasquale Ceratti, A.; Cundari, S.; Zanna, C.; Cortesi, E.; Crino, L. A pilot study on the effect of acetyl-L-carnitine in paclitaxel- and cisplatin-induced peripheral neuropathy. Tumori 2005, 91, 135-138. [CrossRef]

64. Argyriou, A.A.; Cavaletti, G.; Briani, C.; Velasco, R.; Bruna, J.; Campagnolo, M.; Alberti, P.; Bergamo, F.; Cortinovis, D.; Cazzaniga, M.; et al. Clinical pattern and associations of oxaliplatin acute neurotoxicity: A prospective study in 170 patients with colorectal cancer. Cancer 2013, 119, 438-444. [CrossRef]

65. Argyriou, A.A.; Polychronopoulos, P.; Iconomou, G.; Chroni, E.; Kalofonos, H.P. A review on oxaliplatin-induced peripheral nerve damage. Cancer Treat. Rev. 2008, 34, 368-377. [CrossRef] [PubMed]

66. Stein, A.; Arnold, D. Oxaliplatin: A review of approved uses. Expert Opin. Pharmacother. 2012, 13, $125-137$. [CrossRef] [PubMed]

67. Azevedo, M.I.; Pereira, A.F.; Nogueira, R.B.; Rolim, F.E.; Brito, G.A.; Wong, D.V.; Lima-Junior, R.C.; de Albuquerque Ribeiro, R.; Vale, M.L. The antioxidant effects of the flavonoids rutin and quercetin inhibit oxaliplatin-induced chronic painful peripheral neuropathy. Mol. Pain 2013, 9, 53. [CrossRef] [PubMed]

68. Schwingel, T.E.; Klein, C.P.; Nicoletti, N.F.; Dora, C.L.; Hadrich, G.; Bica, C.G.; Lopes, T.G.; da Silva, V.D.; Morrone, F.B. Effects of the compounds resveratrol, rutin, quercetin, and quercetin nanoemulsion on oxaliplatin-induced hepatotoxicity and neurotoxicity in mice. Naunyn Schmiedebergs Arch. Pharm. 2014, 387, 837-848. [CrossRef] [PubMed]

69. Shahid, M.; Subhan, F.; Ahmad, N.; Sewell, R.D.E. The flavonoid 6-methoxyflavone allays cisplatin-induced neuropathic allodynia and hypoalgesia. Biomed. Pharm. 2017, 95, 1725-1733. [CrossRef] [PubMed]

70. Chtourou, Y.; Gargouri, B.; Kebieche, M.; Fetoui, H. Naringin Abrogates Cisplatin-Induced Cognitive Deficits and Cholinergic Dysfunction Through the Down-Regulation of AChE Expression and iNOS Signaling Pathways in Hippocampus of Aged Rats. J. Mol. Neurosci. 2015, 56, 349-362. [CrossRef]

71. Gao, W.; Zan, Y.; Wang, Z.J.; Hu, X.Y.; Huang, F. Quercetin ameliorates paclitaxel-induced neuropathic pain by stabilizing mast cells, and subsequently blocking PKCepsilon-dependent activation of TRPV1. Acta Pharm. Sin. 2016, 37, 1166-1177. [CrossRef]

72. Nadipelly, J.; Sayeli, V.; Kadhirvelu, P.; Shanmugasundaram, J.; Cheriyan, B.V.; Subramanian, V. Effect of certain trimethoxy flavones on paclitaxel - induced peripheral neuropathy in mice. Integr. Med. Res. 2018, 7, 159-167. [CrossRef]

73. Sayeli, V.; Nadipelly, J.; Kadhirvelu, P.; Cheriyan, B.V.; Shanmugasundaram, J.; Subramanian, V. Effect of flavonol and its dimethoxy derivatives on paclitaxel-induced peripheral neuropathy in mice. J. Basic Clin. Physiol. Pharmacol. 2018, 29, 525-535. [CrossRef]

74. Gui, Y.; Zhang, J.; Chen, L.; Duan, S.; Tang, J.; Xu, W.; Li, A. Icariin, a flavonoid with anti-cancer effects, alleviated paclitaxel-induced neuropathic pain in a SIRT1-dependent manner. Mol. Pain 2018, 14, 1744806918768970. [CrossRef]

75. Shao, H.; Xue, Q.; Zhang, F.; Luo, Y.; Zhu, H.; Zhang, X.; Zhang, H.; Ding, W.; Yu, B. Spinal SIRT1 activation attenuates neuropathic pain in mice. PLoS ONE 2014, 9, e100938. [CrossRef]

76. Li, S.; Pan, M.-H.; Lo, C.-Y.; Tan, D.; Wang, Y.; Shahidi, F.; Ho, C.-T. Chemistry and health effects of polymethoxyflavones and hydroxylated polymethoxyflavones. J. Funct. Foods 2009, 1, 2-12. [CrossRef]

77. Boulton, A.J.; Gries, F.A.; Jervell, J.A. Guidelines for the diagnosis and outpatient management of diabetic peripheral neuropathy. Diabet Med. 1998, 15, 508-514. [CrossRef]

78. Kaur, S.; Pandhi, P.; Dutta, P. Painful diabetic neuropathy: An update. Ann. Neurosci. 2011, 18, 168-175. [CrossRef] [PubMed]

79. Tesfaye, S.; Boulton, A.J.; Dickenson, A.H. Mechanisms and management of diabetic painful distal symmetrical polyneuropathy. Diabetes Care 2013, 36, 2456-2465. [CrossRef]

80. Ahmed, N. Advanced glycation endproducts-role in pathology of diabetic complications. Diabetes Res. Clin. Pr. 2005, 67, 3-21. [CrossRef]

81. Toth, C.; Rong, L.L.; Yang, C.; Martinez, J.; Song, F.; Ramji, N.; Brussee, V.; Liu, W.; Durand, J.; Nguyen, M.D.; et al. Receptor for advanced glycation end products (RAGEs) and experimental diabetic neuropathy. Diabetes 2007, 4, 1002-1017. [CrossRef]

82. Du, X.L.; Edelstein, D.; Rossetti, L.; Fantus, I.G.; Goldberg, H.; Ziyadeh, F.; Wu, J.; Brownlee, M. Hyperglycemia-induced mitochondrial superoxide overproduction activates the hexosamine pathway and induces plasminogen activator inhibitor-1 expression by increasing Sp1 glycosylation. Proc. Natl. Acad. Sci. USA 2000, 97, 12222-12226. [CrossRef] 
83. Yamagishi, S.-I.; Uehara, K.; Otsuki, S.; Yagihashi, S. Differential influence of increased polyol pathway on protein kinase $\mathrm{C}$ expressions between endoneurial and epineurial tissues in diabetic mice. J. Neurochem. 2003, 87, 497-507. [CrossRef]

84. Uehara, K.; Yamagishi, S.-I.; Otsuki, S.; Chin, S.; Yagihashi, S. Effects of Polyol Pathway Hyperactivity on Protein Kinase C Activity, Nociceptive Peptide Expression, and Neuronal Structure in Dorsal Root Ganglia in Diabetic Mice. Diabetes 2004, 53, 3239-3247. [CrossRef]

85. Cameron, N.E.; Cotter, M.A. Effects of protein kinase Cbeta inhibition on neurovascular dysfunction in diabetic rats: Interaction with oxidative stress and essential fatty acid dysmetabolism. Diabetes Metab. Res. Rev. 2002, 18, 315-323. [CrossRef] [PubMed]

86. Das Evcimen, N.; King, G.L. The role of protein kinase C activation and the vascular complications of diabetes. Pharm. Res. 2007, 55, 498-510. [CrossRef] [PubMed]

87. Du, X.; Matsumura, T.; Edelstein, D.; Rossetti, L.; Zsengellér, Z.; Szabó, C.; Brownlee, M. Inhibition of GAPDH activity by poly(ADP-ribose) polymerase activates three major pathways of hyperglycemic damage in endothelial cells. J. Clin. Investig. 2003, 112, 1049-1057. [CrossRef]

88. Obrosova, I.G.; Julius, U.A. Role for poly(ADP-ribose) polymerase activation in diabetic nephropathy, neuropathy and retinopathy. Curr. Vasc. Pharm. 2005, 3, 267-283. [CrossRef] [PubMed]

89. Addepalli, V.; Suryavanshi, S.V. Catechin attenuates diabetic autonomic neuropathy in streptozotocin induced diabetic rats. Biomed. Pharm. 2018, 108, 1517-1523. [CrossRef]

90. Li, M.; Li, Q.; Zhao, Q.; Zhang, J.; Lin, J. Luteolin improves the impaired nerve functions in diabetic neuropathy: Behavioral and biochemical evidences. Int. J. Clin. Exp. Pathol. 2015, 8, 10112-10120. [PubMed]

91. Mirshekar, M.; Roghani, M.; Khalili, M.; Baluchnejadmojarad, T.; Arab Moazzen, S. Chronic oral pelargonidin alleviates streptozotocin-induced diabetic neuropathic hyperalgesia in rat: Involvement of oxidative stress. Iran. Biomed. J. 2010, 14, 33-39.

92. Tian, R.; Yang, W.; Xue, Q.; Gao, L.; Huo, J.; Ren, D.; Chen, X. Rutin ameliorates diabetic neuropathy by lowering plasma glucose and decreasing oxidative stress via Nrf2 signaling pathway in rats. Eur. J. Pharm. 2016, 771, 84-92. [CrossRef]

93. Valsecchi, A.E.; Franchi, S.; Panerai, A.E.; Rossi, A.; Sacerdote, P.; Colleoni, M. The soy isoflavone genistein reverses oxidative and inflammatory state, neuropathic pain, neurotrophic and vasculature deficits in diabetes mouse model. Eur. J. Pharm. 2011, 650, 694-702. [CrossRef]

94. Feldman, E.L.; Stevens, M.J.; Thomas, P.K.; Brown, M.B.; Canal, N.; Greene, D.A. A practical two-step quantitative clinical and electrophysiological assessment for the diagnosis and staging of diabetic neuropathy. Diabetes Care 1994, 17, 1281-1289. [CrossRef]

95. Perkins, B.A.; Olaleye, D.; Zinman, B.; Bril, V. Simple screening tests for peripheral neuropathy in the diabetes clinic. Diabetes Care 2001, 24, 250-2506. [CrossRef] [PubMed]

96. Al-Rejaie, S.S.; Aleisa, A.M.; Abuohashish, H.M.; Parmar, M.Y.; Ola, M.S.; Al-Hosaini, A.A.; Ahmed, M.M. Naringenin neutralises oxidative stress and nerve growth factor discrepancy in experimental diabetic neuropathy. Neurol. Res. 2015, 37, 924-933. [CrossRef] [PubMed]

97. Bachewal, P.; Gundu, C.; Yerra, V.G.; Kalvala, A.K.; Areti, A.; Kumar, A. Morin exerts neuroprotection via attenuation of ROS induced oxidative damage and neuroinflammation in experimental diabetic neuropathy. Biofactors 2018, 44, 109-122. [CrossRef] [PubMed]

98. Kishore, L.; Kaur, N.; Singh, R. Effect of Kaempferol isolated from seeds of Eruca sativa on changes of pain sensitivity in Streptozotocin-induced diabetic neuropathy. Inflammopharmacology 2018, 26, 993-1003. [CrossRef] [PubMed]

99. Zhao, X.; Wang, C.; Cui, W.G.; Ma, Q.; Zhou, W.H. Fisetin exerts antihyperalgesic effect in a mouse model of neuropathic pain: Engagement of spinal serotonergic system. Sci. Rep. 2015, 5, 9043. [CrossRef]

100. Cardozo, L.F.; Pedruzzi, L.M.; Stenvinkel, P.; Stockler-Pinto, M.B.; Daleprane, J.B.; Leite, M., Jr.; Mafra, D. Nutritional strategies to modulate inflammation and oxidative stress pathways via activation of the master antioxidant switch Nrf2. Biochimie 2013, 95, 1525-1533. [CrossRef]

101. Agca, C.A.; Tuzcu, M.; Hayirli, A.; Sahin, K. Taurine ameliorates neuropathy via regulating NF-kappaB and Nrf2/HO-1 signaling cascades in diabetic rats. Food Chem. Toxicol. 2014, 71, 116-121. [CrossRef]

102. Kumar, A.; Mittal, R. Nrf2: A potential therapeutic target for diabetic neuropathy. Inflammopharmacology 2017, 25, 393-402. [CrossRef] 
103. Valavanidis, A.; Vlachogianni, T.; Fiotakis, C. 8-hydroxy-2'-deoxyguanosine (8-OHdG): A critical biomarker of oxidative stress and carcinogenesis. J. Environ. Sci. Health C Environ. Carcinog. Ecotoxicol. Rev. 2009, 27, 120-139. [CrossRef]

104. Pittenger, G.; Vinik, A. Nerve growth factor and diabetic neuropathy. Exp. Diabesity Res. 2003, 4, $271-285$. [CrossRef]

105. Kawasaki, Y.; Xu, Z.Z.; Wang, X.; Park, J.Y.; Zhuang, Z.Y.; Tan, P.H.; Gao, Y.J.; Roy, K.; Corfas, G.; Lo, E.H.; et al. Distinct roles of matrix metalloproteases in the early- and late-phase development of neuropathic pain. Nat. Med. 2008, 14, 331-336. [CrossRef] [PubMed]

106. Kuhad, A.; Singh, P.; Chopra, K. Matrix metalloproteinases: Potential therapeutic target for diabetic neuropathic pain. Expert Opin. Targets 2015, 19, 177-185. [CrossRef] [PubMed]

107. Yong, V.W. Metalloproteinases: Mediators of pathology and regeneration in the CNS. Nat. Rev. Neurosci. 2005, 6, 931-944. [CrossRef]

108. Naik, A.K.; Tandan, S.K.; Dudhgaonkar, S.P.; Jadhav, S.H.; Kataria, M.; Prakash, V.R.; Kumar, D. Role of oxidative stress in pathophysiology of peripheral neuropathy and modulation by N-acetyl-L-cysteine in rats. Eur. J. Pain 2006, 10, 573-579. [CrossRef]

109. Liu, W.-T.; Han, Y.; Liu, Y.-P.; Song, A.A.; Barnes, B.; Song, X.-J. Spinal matrix metalloproteinase-9 contributes to physical dependence on morphine in mice. J. Neurosci. Off. J. Soc. Neurosci. 2010, 30, 7613-7623. [CrossRef]

110. Pittenger, G.L.; Mehrabyan, A.; Simmons, K.; Dublin, C.; Barlow, P.; Vinik, A.I. Small fiber neuropathy is associated with the metabolic syndrome. Metab. Syndr. Relat. Disord. 2005, 3, 113-121. [CrossRef]

111. Kandhare, A.D.; Raygude, K.S.; Ghosh, P.; Ghule, A.E.; Bodhankar, S.L. Neuroprotective effect of naringin by modulation of endogenous biomarkers in streptozotocin induced painful diabetic neuropathy. Fitoterapia 2012, 83, 650-659. [CrossRef]

112. Li, P.; Xiong, D.L.; Sun, W.P.; Xu, S.Y. Effects of baicalin on diabetic neuropathic pain involving transient receptor potential vanilloid 1 in the dorsal root ganglia of rats. Neuroreport 2018, 29, 1492-1498. [CrossRef]

113. Visnagri, A.; Kandhare, A.D.; Chakravarty, S.; Ghosh, P.; Bodhankar, S.L. Hesperidin, a flavanoglycone attenuates experimental diabetic neuropathy via modulation of cellular and biochemical marker to improve nerve functions. Pharm. Biol. 2014, 52, 814-828. [CrossRef]

114. Raposo, D.; Morgado, C.; Pereira-Terra, P.; Tavares, I. Nociceptive spinal cord neurons of laminae I-III exhibit oxidative stress damage during diabetic neuropathy which is prevented by early antioxidant treatment with epigallocatechin-gallate (EGCG). Brain Res. Bull. 2015, 110, 68-75. [CrossRef]

115. Liu, M.; Liao, K.; Yu, C.; Li, X.; Liu, S.; Yang, S. Puerarin alleviates neuropathic pain by inhibiting neuroinflammation in spinal cord. Mediat. Inflamm. 2014, 2014, 485927. [CrossRef] [PubMed]

116. Dyck, P.J.; Larson, T.; O’Brien, P.; Velosa, J. Patterns of quantitative sensation testing of hypoesthesia and hyperalgesia are predictive of diabetic polyneuropathy: A study of three cohorts. Nerve growth factor study group. Diabetes Care 2000, 23, 510-517. [CrossRef] [PubMed]

117. Freshwater, J.D.; Calcutt, N.A. Low doses of formalin reveal allodynia in diabetic rats. J. Neuropathic Pain Symptom Palliation 2005, 1, 39-46. [CrossRef]

118. Calcutt, N.; Freshwater, J.; Mizisin, A. Prevention of sensory disorders in diabetic Sprague-Dawley rats by aldose reductase inhibition or treatment with ciliary neurotrophic factor. Diabetologia 2004, 47, 718-724. [CrossRef] [PubMed]

119. Stavniichuk, R.; Drel, V.R.; Shevalye, H.; Maksimchyk, Y.; Kuchmerovska, T.M.; Nadler, J.L.; Obrosova, I.G. Baicalein alleviates diabetic peripheral neuropathy through inhibition of oxidative-nitrosative stress and p38 MAPK activation. Exp. Neurol. 2011, 230, 106-113. [CrossRef]

120. Matsuoka, A.; Mitsuma, A.; Maeda, O.; Kajiyama, H.; Kiyoi, H.; Kodera, Y.; Nagino, M.; Goto, H.; Ando, Y. Quantitative assessment of chemotherapy-induced peripheral neurotoxicity using a point-of-care nerve conduction device. Cancer Sci. 2016, 107, 1453-1457. [CrossRef]

121. Cameron, N.E.; Cotter, M.A.; Jack, A.M.; Basso, M.D.; Hohman, T.C. Protein kinase C effects on nerve function, perfusion, $\mathrm{Na}(+), \mathrm{K}(+)$-ATPase activity and glutathione content in diabetic rats. Diabetologia 1999, 42, 1120-1130. [CrossRef]

122. Ding, Y.; Dai, X.; Zhang, Z.; Jiang, Y.; Ma, X.; Cai, X.; Li, Y. Proanthocyanidins protect against early diabetic peripheral neuropathy by modulating endoplasmic reticulum stress. J. Nutr. Biochem. 2014, 25, 765-772. [CrossRef] 
123. Akbar, S.; Subhan, F.; Karim, N.; Shahid, M.; Ahmad, N.; Ali, G.; Mahmood, W.; Fawad, K. 6-Methoxyflavanone attenuates mechanical allodynia and vulvodynia in the streptozotocin-induced diabetic neuropathic pain. Biomed. Pharmacother. 2016, 84, 962-971. [CrossRef]

124. Colburn, R.W.; Rickman, A.J.; DeLeo, J.A. The effect of site and type of nerve injury on spinal glial activation and neuropathic pain behavior. Exp. Neurol. 1999, 157, 289-304. [CrossRef]

125. Bennett, G.J.; Xie, Y.-K. A peripheral mononeuropathy in rat that produces disorders of pain sensation like those seen in man. PAIN 1988, 33, 87-107. [CrossRef]

126. Colleoni, M.; Sacerdote, P. Murine models of human neuropathic pain. Biochim. Biophys. Acta 2010, 1802, 924-933. [CrossRef] [PubMed]

127. Austin, P.J.; Wu, A.; Moalem-Taylor, G. Chronic constriction of the sciatic nerve and pain hypersensitivity testing in rats. J. Vis. Exp. Jove 2012, 3393. [CrossRef] [PubMed]

128. Bertozzi, M.M.; Rossaneis, A.C.; Fattori, V.; Longhi-Balbinot, D.T.; Freitas, A.; Cunha, F.Q.; Alves-Filho, J.C.; Cunha, T.M.; Casagrande, R.; Verri, W.A., Jr. Diosmin reduces chronic constriction injury-induced neuropathic pain in mice. Chem. Biol. Interact. 2017, 273, 180-189. [CrossRef]

129. Carballo-Villalobos, A.I.; González-Trujano, M.-E.; Pellicer, F.; López-Muñoz, F.J. Antihyperalgesic Effect of Hesperidin Improves with Diosmin in Experimental Neuropathic Pain. Biomed. Res. Int. 2016, 2016, 8263463. [CrossRef]

130. Kaur, G.; Bedi, O.; Sharma, N.; Singh, S.; Deshmukh, R.; Kumar, P. Anti-hyperalgesic and anti-nociceptive potentials of standardized grape seed proanthocyanidin extract against CCI-induced neuropathic pain in rats. J. Basic Clin. Physiol. Pharm. 2016, 27, 9-17. [CrossRef]

131. Zhang, G.; Liu, N.; Zhu, C.; Ma, L.; Yang, J.; Du, J.; Zhang, W.; Sun, T.; Niu, J.; Yu, J. Antinociceptive effect of isoorientin against neuropathic pain induced by the chronic constriction injury of the sciatic nerve in mice. Int. Immunopharmacol. 2019, 75, 105753. [CrossRef]

132. Komirishetty, P.; Areti, A.; Sistla, R.; Kumar, A. Morin Mitigates Chronic Constriction Injury (CCI)-Induced Peripheral Neuropathy by Inhibiting Oxidative Stress Induced PARP Over-Activation and Neuroinflammation. Neurochem. Res. 2016, 41, 2029-2042. [CrossRef]

133. Kuang, X.; Huang, Y.; Gu, H.F.; Zu, X.Y.; Zou, W.Y.; Song, Z.B.; Guo, Q.L. Effects of intrathecal epigallocatechin gallate, an inhibitor of Toll-like receptor 4, on chronic neuropathic pain in rats. Eur. J. Pharm. 2012, 676, 51-56. [CrossRef]

134. Xifró, X.; Vidal-Sancho, L.; Boadas-Vaello, P.; Turrado, C.; Alberch, J.; Puig, T.; Verdú, E. Novel epigallocatechin-3-gallate (EGCG) derivative as a new therapeutic strategy for reducing neuropathic pain after chronic constriction nerve injury in mice. PLOS ONE 2015, 10, e0123122. [CrossRef]

135. Valsecchi, A.E.; Franchi, S.; Panerai, A.E.; Sacerdote, P.; Trovato, A.E.; Colleoni, M. Genistein, a natural phytoestrogen from soy, relieves neuropathic pain following chronic constriction sciatic nerve injury in mice: Anti-inflammatory and antioxidant activity. J. Neurochem. 2008, 107, 230-240. [CrossRef] [PubMed]

136. Civi, S.; Emmez, G.; Dere, U.A.; Borcek, A.O.; Emmez, H. Effects of quercetin on chronic constriction nerve injury in an experimental rat model. Acta Neurochir. (Wien.) 2016, 158, 959-965; discussion 965.

137. Hara, K.; Haranishi, Y.; Terada, T.; Takahashi, Y.; Nakamura, M.; Sata, T. Effects of intrathecal and intracerebroventricular administration of luteolin in a rat neuropathic pain model. Pharm. Biochem. Behav. 2014, 125, 78-84. [CrossRef] [PubMed]

138. Goecks, C.S.; Horst, A.; Moraes, M.S.; Scheid, T.; Kolberg, C.; Bello-Klein, A.; Partata, W.A. Assessment of oxidative parameters in rat spinal cord after chronic constriction of the sciatic nerve. Neurochem. Res. 2012, 37, 1952-1958. [CrossRef]

139. Choi, D.C.; Lee, J.Y.; Lim, E.J.; Baik, H.H.; Oh, T.H.; Yune, T.Y. Inhibition of ROS-induced p38MAPK and ERK activation in microglia by acupuncture relieves neuropathic pain after spinal cord injury in rats. Exp. Neurol. 2012, 236, 268-282. [CrossRef] [PubMed]

140. Kurutas, E.B. The importance of antioxidants which play the role in cellular response against oxidative/nitrosative stress: Current state. Nutr. J. 2016, 15, 71. [CrossRef]

141. Tal, M. A novel antioxidant alleviates heat hyperalgesia in rats with an experimental painful peripheral neuropathy. Neuroreport 1996, 7, 1382-1384. [CrossRef] 
142. Khalil, Z.; Liu, T.; Helme, R.D. Free radicals contribute to the reduction in peripheral vascular responses and the maintenance of thermal hyperalgesia in rats with chronic constriction injury. Pain 1999, 79, 31-37. [CrossRef]

143. Obrosova, I.G.; Li, F.; Abatan, O.I.; Forsell, M.A.; Komjati, K.; Pacher, P.; Szabo, C.; Stevens, M.J. Role of poly(ADP-Ribose) polymerase activation in diabetic neuropathy. Diabetes 2004, 53, 711-720. [CrossRef]

144. Sommer, C.; Kress, M. Recent findings on how proinflammatory cytokines cause pain: Peripheral mechanisms in inflammatory and neuropathic hyperalgesia. Neurosci. Lett. 2004, 361, 184-187. [CrossRef]

145. Jagtap, P.; Szabo, C. Poly(ADP-ribose) polymerase and the therapeutic effects of its inhibitors. Nat. Rev. Drug Discov. 2005, 4, 421-440. [CrossRef] [PubMed]

146. Ha, H.C.; Snyder, S.H. Poly(ADP-ribose) polymerase is a mediator of necrotic cell death by ATP depletion. Proc. Natl. Acad. Sci. USA 1999, 96, 13978-13982. [CrossRef] [PubMed]

147. Janeway, C.A., Jr.; Medzhitov, R. Innate immune recognition. Annu. Rev. Immunol. 2002, 20, $197-216$. [CrossRef] [PubMed]

148. Akira, S.; Uematsu, S.; Takeuchi, O. Pathogen recognition and innate immunity. Cell 2006, 124, $783-801$. [CrossRef]

149. Morioka, N.; Kodama, K.; Tomori, M.; Yoshikawa, K.; Saeki, M.; Nakamura, Y.; Zhang, F.F.; Hisaoka-Nakashima, K.; Nakata, Y. Stimulation of nuclear receptor REV-ERBs suppresses production of pronociceptive molecules in cultured spinal astrocytes and ameliorates mechanical hypersensitivity of inflammatory and neuropathic pain of mice. Brain Behav. Immun. 2019, 78, 116-130. [CrossRef]

150. Kuiper, G.G.J.M.; Carlsson, B.; Grandien, K.; Enmark, E.; Häggblad, J.; Nilsson, S.; Gustafsson, J.-A.K. Comparison of the Ligand Binding Specificity and Transcript Tissue Distribution of Estrogen Receptors $\alpha$ and $\beta$. Endocrinology 1997, 138, 863-870. [CrossRef]

151. Wu, L.-J.; Zhuo, M. Targeting the NMDA receptor subunit NR2B for the treatment of neuropathic pain. Neurotherapeutics 2009, 6, 693-702. [CrossRef]

152. Pérez, J.; Ware, M.A.; Chevalier, S.; Gougeon, R.; Shir, Y. Dietary Omega-3 Fatty Acids May Be Associated with Increased Neuropathic Pain in Nerve-Injured Rats. Anesth. Analg. 2005, 101, 444-448. [CrossRef]

153. Martin, Y.B.; Avendaño, C. Effects of removal of dietary polyunsaturated fatty acids on plasma extravasation and mechanical allodynia in a trigeminal neuropathic pain model. Mol. Pain 2009, 5, 8. [CrossRef]

154. Ko, G.D.; Nowacki, N.B.; Arseneau, L.; Eitel, M.; Hum, A. Omega-3 Fatty Acids for Neuropathic Pain: Case Series. Clin. J. Pain 2010, 26, 168-172. [CrossRef]

155. Seltzer, Z.E.; Dubner, R.; Shir, Y. A novel behavioral model of neuropathic pain disorders produced in rats by partial sciatic nerve injury. Pain 1990, 43, 205-218. [CrossRef]

156. Malmberg, A.B.; Basbaum, A.I. Partial sciatic nerve injury in the mouse as a model of neuropathic pain: Behavioral and neuroanatomical correlates. PAIN 1998, 76, 215-222. [CrossRef]

157. Bura, S.A.; Nadal, X.; Ledent, C.; Maldonado, R.; Valverde, O. A 2A adenosine receptor regulates glia proliferation and pain after peripheral nerve injury. Pain 2008, 140, 95-103. [CrossRef] [PubMed]

158. Maeda, T.; Kiguchi, N.; Kobayashi, Y.; Ozaki, M.; Kishioka, S. Pioglitazone attenuates tactile allodynia and thermal hyperalgesia in mice subjected to peripheral nerve injury. J. Pharm. Sci. 2008, 108, 341-347. [CrossRef] [PubMed]

159. Morita, K.; Motoyama, N.; Kitayama, T.; Morioka, N.; Kifune, K.; Dohi, T. Spinal antiallodynia action of glycine transporter inhibitors in neuropathic pain models in mice. J. Pharm. Exp. 2008, 326, 633-645. [CrossRef]

160. Tanabe, M.; Nagatani, Y.; Saitoh, K.; Takasu, K.; Ono, H. Pharmacological assessments of nitric oxide synthase isoforms and downstream diversity of NO signaling in the maintenance of thermal and mechanical hypersensitivity after peripheral nerve injury in mice. Neuropharmacology 2009, 56, 702-708. [CrossRef]

161. Decosterd, I.; Woolf, C.J. Spared nerve injury: An animal model of persistent peripheral neuropathic pain. Pain 2000, 87, 149-158. [CrossRef]

162. Shields, S.D.; Eckert, W.A., 3rd; Basbaum, A.I. Spared nerve injury model of neuropathic pain in the mouse: A behavioral and anatomic analysis. J. Pain 2003, 4, 465-470. [CrossRef]

163. Kim, S.H.; Chung, J.M. An experimental model for peripheral neuropathy produced by segmental spinal nerve ligation in the rat. Pain 1992, 50, 355-363. [CrossRef] 
164. Mogil, J.S.; Wilson, S.G.; Bon, K.; Lee, S.E.; Chung, K.; Raber, P.; Pieper, J.O.; Hain, H.S.; Belknap, J.K.; Hubert, L.; et al. Heritability of nociception I: Responses of 11 inbred mouse strains on 12 measures of nociception. Pain 1999, 80, 67-82. [CrossRef]

165. Kiso, T.; Watabiki, T.; Tsukamoto, M.; Okabe, M.; Kagami, M.; Nishimura, K.; Aoki, T.; Matsuoka, N. Pharmacological characterization and gene expression profiling of an L5/L6 spinal nerve ligation model for neuropathic pain in mice. Neuroscience 2008, 153, 492-500. [CrossRef] [PubMed]

166. Cherng, C.-H.; Lee, K.-C.; Chien, C.-C.; Chou, K.-Y.; Cheng, Y.-C.; Hsin, S.-T.; Lee, S.-O.; Shen, C.-H.; Tsai, R.-Y.; Wong, C.-S. Baicalin ameliorates neuropathic pain by suppressing HDAC1 expression in the spinal cord of spinal nerve ligation rats. J. Formos. Med. Assoc. 2014, 113, 513-520. [CrossRef] [PubMed]

167. Choi, J.I.; Kim, W.M.; Lee, H.G.; Kim, Y.O.; Yoon, M.H. Role of neuronal nitric oxide synthase in the antiallodynic effects of intrathecal EGCG in a neuropathic pain rat model. Neurosci. Lett. 2012, 510, 53-57. [CrossRef] [PubMed]

168. Hagenacker, T.; Hillebrand, I.; Wissmann, A.; Büsselberg, D.; Schäfers, M. Anti-allodynic effect of the flavonoid myricetin in a rat model of neuropathic pain: Involvement of p38 and protein kinase C mediated modulation of Ca2+ channels. Eur. J. Pain 2010, 14, 992-998. [CrossRef] [PubMed]

169. Ji, C.; Xu, Y.; Han, F.; Sun, D.; Zhang, H.; Li, X.; Yao, X.; Wang, H. Quercetin alleviates thermal and cold hyperalgesia in a rat neuropathic pain model by inhibiting Toll-like receptor signaling. Biomed. Pharm. 2017, 94, 652-658. [CrossRef]

170. Lu, Y.; Jiang, B.C.; Cao, D.L.; Zhang, Z.J.; Zhang, X.; Ji, R.R.; Gao, Y.J. TRAF6 upregulation in spinal astrocytes maintains neuropathic pain by integrating TNF-alpha and IL-1beta signaling. Pain 2014, 155, 2618-2629. [CrossRef]

171. Haberland, M.; Montgomery, R.L.; Olson, E.N. The many roles of histone deacetylases in development and physiology: Implications for disease and therapy. Nat. Rev. Genet. 2009, 10, 32-42. [CrossRef]

172. Bai, G.; Wei, D.; Zou, S.; Ren, K.; Dubner, R. Inhibition of class II histone deacetylases in the spinal cord attenuates inflammatory hyperalgesia. Mol. Pain 2010, 6, 51. [CrossRef] [PubMed]

173. Chiechio, S.; Copani, A.; Zammataro, M.; Battaglia, G.; Gereau, R.W.T.; Nicoletti, F. Transcriptional regulation of type-2 metabotropic glutamate receptors: An epigenetic path to novel treatments for chronic pain. Trends Pharm. Sci. 2010, 31, 153-160. [CrossRef] [PubMed]

174. Guan, Y.; Yaster, M.; Raja, S.N.; Tao, Y.X. Genetic knockout and pharmacologic inhibition of neuronal nitric oxide synthase attenuate nerve injury-induced mechanical hypersensitivity in mice. Mol. Pain 2007, 3, 29. [CrossRef]

175. Knowles, R.G.; Moncada, S. Nitric oxide synthases in mammals. Biochem. J. 1994, 298, 249-258. [CrossRef] [PubMed]

176. Sung, C.S.; Wen, Z.H.; Chang, W.K.; Ho, S.T.; Tsai, S.K.; Chang, Y.C.; Wong, C.S. Intrathecal interleukin-1beta administration induces thermal hyperalgesia by activating inducible nitric oxide synthase expression in the rat spinal cord. Brain Res. 2004, 1015, 145-153. [CrossRef] [PubMed]

177. Bryan, N.S.; Bian, K.; Murad, F. Discovery of the nitric oxide signaling pathway and targets for drug development. Front. Biosci. (Landmark Ed.) 2009, 14, 1-18. [CrossRef]

178. Aswar, M.; Kute, P.; Mahajan, S.; Mahajan, U.; Nerurkar, G.; Aswar, U. Protective effect of hesperetin in rat model of partial sciatic nerve ligation induced painful neuropathic pain: An evidence of anti-inflammatory and anti-oxidative activity. Pharmacol. Biochem. Behav. 2014, 124, 101-107. [CrossRef]

179. Muto, N.; Matsuoka, Y.; Arakawa, K.; Kurita, M.; Omiya, H.; Taniguchi, A.; Kaku, R.; Morimatsu, H. Quercetin Attenuates Neuropathic Pain in Rats with Spared Nerve Injury. Acta Med. Okayama 2018, 72, 457-465.

180. Vaya, J.; Tavori, H.; Khatib, S. Structure-Activity Relationships of Flavonoids. Curr. Org. Chem. 2011, 15, 2641-2657.

181. Modak, B.; Contreras, M.L.; Gonzalez-Nilo, F.; Torres, R. Structure-antioxidant activity relationships of flavonoids isolated from the resinous exudate of Heliotropium sinuatum. Bioorg. Med. Chem. Lett. 2005, 15, 309-312. [CrossRef]

182. Lin, C.-Z.; Zhu, C.-C.; Hu, M.; Wu, A.-Z.; Bairu, Z.-D.; Kangsa, S.-Q. Structure-activity relationships of antioxidant activity in vitro about flavonoids isolated from Pyrethrum tatsienense. J. Intercult Ethnopharmacol. 2014, 3, 123-127. [CrossRef] 
183. Lee, S.K.; Nam, K.A.; Hoe, Y.H.; Min, H.Y.; Kim, E.Y.; Ko, H.; Song, S.; Lee, T.; Kim, S. Synthesis and evaluation of cytotoxicity of stilbene analogues. Arch. Pharm. Res. 2003, 26, 253-257. [CrossRef]

184. Basu, P.; Maier, C. Phytoestrogens and breast cancer: In vitro anticancer activities of isoflavones, lignans, coumestans, stilbenes and their analogs and derivatives. Biomed. Pharmacother. 2018, 107, 1648-1666. [CrossRef]

Sample Availability: Samples of the compounds are not available from the authors.

(C) 2020 by the authors. Licensee MDPI, Basel, Switzerland. This article is an open access article distributed under the terms and conditions of the Creative Commons Attribution (CC BY) license (http://creativecommons.org/licenses/by/4.0/). 